\title{
Which Workers are Most Exposed to CoviD-19 and Social Distancing Effects in a Dual Labour Market?*
}

Recibido: 2 de marzo de 2021 - Aceptado: 30 de abril de 2021

Doi: https://doi.org/10.12804/revistas.urosario.edu.co/economia/a.10549

\author{
Jeisson Cárdenas ${ }^{\dagger}$ \\ Jaime Montana $\ddagger$ \\ Derek Bosworth§
}

Abstract

This paper provides evidence for the different potential effects of covid-19 on formal and informal employment, using the work-from-home (Dingel \& Neiman, 2020; Saltiel, 2020) and the proximity occupation approaches (Mongey et al., 2020) in Colombia. We found that only $13 \%$ of informal employment positions can be performed from home (remotely) and that the figure for formal employment is twice as large (20\%). We recoded the raw occupational responses of the Colombian Household Survey to a granular level to directly combine occupational information from two sources: $\mathrm{O}^{*}$ NET and STEP. We then calculated work-from-home estimates, extracting cohesive results from both sources. We investigated

* We thank David Margolis, Juan Miguel Gallego, Hector Moreno, and Emanuele Franceschi for their comments. J. Cárdenas thanks the "Inclusión productiva y social: programas y políticas para la promoción de una economía formal, Código 60185, que conforma la Alianza EFI, bajo el Contrato de Recuperación Contingente No. FP44842-2202018" program.

† University of Warwick. Email: jeisson.cardenas-rubio@warwick.ac.uk (corresponding author). ORCID: https://orcid.org/0000-0003-0177-2785

$\ddagger \quad$ Paris School of Economics and Turin University. Email: jaime.montana@psemail. eu ORCID: https://orcid.org/0000-0003-0299-6238

$\S \quad$ University of Warwick. Email: derek.bosworth@warwick.ac.uk

To cite this article: Cárdenas, J., Montana, J., \& Bosworth, D. (2021). Which Workers are Most Exposed to Covid-19 and Social Distancing Effects in a Dual Labour Market?. Revista de Economía del Rosario, 24(2), 1-44. https://doi.org/10.12804/revistas.urosario.edu. co/economia/a.10549 
how personal and household characteristics relate to work-from-home and proximity and provide sound evidence for a larger effect on the informal population and its association with vulnerability (lower income and education levels, no internet access, poor working conditions). Standard employment policies will not impact directly on the most vulnerable populations in developing countries where informal employment is the norm.

Keywords: covid-19; occupational characteristics; informality; work-from-home; proximity. JEL Classification: J46, J82.

\title{
¿Qué trabajadores están más expuestos al covid-19 y los efectos del distanciamiento social en un mercado laboral dual?
}

\author{
Resumen
}

Este artículo proporciona evidencia de los posibles efectos del covid-19 en el empleo formal e informal en Colombia, utilizando los índices de teletrabajo (Dingel \& Neiman, 2020; Saltiel, 2020) y de proximidad (Mongey et al., 2020). Encontramos que solo el $13 \%$ de los puestos de trabajo informal se pueden realizar desde casa (de forma remota) y mientras que esta cifra para el empleo formal es el doble (20\%). Para realizar las correspondientes estimaciones, recodificamos los títulos ocupacionales de la Encuesta de Hogares de Colombia para complementarlas con la información ocupacional de la $\mathrm{O}^{*}$ NET y STEP. Investigamos cómo las características personales y del hogar se relacionan con el trabajo desde el hogar y la proximidad y encontramos evidencia de un posible mayor efecto negativo en la población informal y en condiciones de vulnerabilidad (menores niveles de ingresos y educación, falta de acceso a Internet, insuficientes condiciones de trabajo). Asimismo, señalamos que las políticas de empleo estándar no afectarán directamente a las poblaciones más vulnerables de los países en desarrollo donde el empleo informal es la norma.

Palabras clave: covid-19; características ocupacionales; informalidad; teletrabajo; proximidad.

JEL Clasificación: J46, J82.

\section{Quais trabalhadores estão mais expostos ao covid-19 e aos efeitos do distanciamento social em um mercado dual de trabalho?}

\author{
Resumo
}

Este artigo fornece evidências dos possíveis efeitos da covid-19 sobre o emprego formal e informal na Colômbia, usando os índices de teletrabalho (Dingel \& Neiman, 2020; Saltiel, 2020) e de proximidade (Mongey et al., 2020). Descobrimos que apenas $13 \%$ dos empregos informais podem ser realizados em casa (remotamente) enquanto esse número é duplicado (20\%) no caso dos empregos formais. Para realizar as estimativas correspondentes, recodificamos os títulos ocupacionais da Pesquisa Domiciliar da Colômbia para complementá-los com as informações ocupacionais do o*net e step. Investigamos como 
as características pessoais e domésticas estão relacionadas ao trabalho em casa e com a proximidade social e encontramos evidências de um possível efeito negativo maior sobre a população informal e em condições de vulnerabilidade (menores níveis de renda e escolaridade, falta de acesso à Internet, condições de trabalho insuficientes). Também observamos que as políticas de emprego padrão não afetarão diretamente as populações mais vulneráveis dos países em desenvolvimento, onde o emprego informal é a norma.

Palavras-chave: covid-19; características ocupacionais; informalidade; teletrabalho; proximidade.

Classificação JEL: J46, J82.

\section{Introduction}

The spread of the covid-19 virus has affected global economic activity substantially. However, its likely effects on the informal sector have not yet been quantified accurately. This seems a serious omission given that informal workers, who are already more vulnerable to income shocks, comprise the largest share of the global workforce. In 2019, for example, the International Labour Organization (ILO) estimated that $61 \%$ of the total world employment was informal. Bonnet et al. (2019), for example, valuated that the incidence of informality in emerging and developing economies accounts for $67 \%$ and $90 \%$ of total employment, respectively. Such workers are particularly concentrated amongst developing countries, where the informal sector often accounts for more than half of the GDP and employment in low-income countries (Pratap \& Quintin, 2006, p. 1). The relation between informal employment and lower income has been previously studied, especially for Latin American countries (Perry et al., 2007). Even if informal work is present across all occupations and income levels, a clear overlap exists between informality and low income, low productivity, and poorer households and worker conditions.

This need to focus on the relationship between covid-19 and informality is crucial because the nature of both employment and the employment relationship varies with the degree of informality (Williams, 2014). In terms of the nature of employment, this paper demonstrates the differences in the occupations that (i) can be performed from home (remotely) during social distancing measures and (ii) are associated with proximity (e.g., face-to-face) between workers and clients. In terms of the nature of the employment contract, informal employees (i) tend to be uninsured for personal and economic shocks (e. g., unemployment insurance) without the personal wealth to cover for such contingencies and (ii) do not contribute to social protection, thus 
experiencing impediments to healthcare access, ${ }^{1}$ sick and maternity leaves, and have to rely, as far as one exists, on a social safety net.

A lack of recognised qualifications and occupations, which allow access to the formal sector, along with weak social protection associate with the necessity of work amongst those in the informal sector, often in self-employment, despite the emergence of covid-19 (Margolis, 2014). The dilemma that the lack of savings and other forms of support create for the imperative of working amid informal workers is vividly illustrated in the works of ILO (2020a, 2020b). The imperative of work amongst informal occupations in developing countries is far from entrepreneurial activities undertaken by choice. Therefore, it is important to understand how the formal and informal segments duality of developing economies help to explain the differences of the covid-19 effects across countries, regions, sectors, and occupations. Repercussions also differ through time: initial diffusion of the virus, through the first stages of social distancing to the release from confinement shifts that strain to different occupations. While all these dimensions are considered in the present paper, the focus is to understand how the risks of contracting covid-19 differ for workers within the poorer (informal) and richer (formal) segments of a dual economy and how this can be used to inform the actions of policymakers.

The first economic potential effects of covid-19 were measured for the us economy. Del Rio-Chanona et al. (2020) identified that big drops in the GDP occurred in nonessential sectors, where work activities cannot be performed at home. Dingel and Neiman (2020) demonstrated that the consequences of social distancing vary across regions, sectors, and occupations. In particular, they presented evidence of a positive relationship between a country's GDP and its share of work-from-home (teleworkable) occupations. This result suggests that less-developed countries will have a harder time with the imposition of confinement measures because individuals and employers do not have access to the necessary organisational and Iт infrastructures to work in this way. Mongey et al. (2020) calculated covid-19's effects across industries and occupations using two different measures: low work-from-home and high-proximity occupations, including those associated with intensive faceto-face interactions. These indicators revealed vulnerable populations are more likely to be affected and that the effects will be larger for developing countries (Saltiel, 2020). These results also have potential implications as to which groups should, in principle, be the first to receive the covid-vaccine.

1 See Chakrabarti et al. (2020) in the case of us health insurance. 
This paper provides evidence regarding the share of workers who are most exposed to coviD-19 and social distancing effects in Colombia, a developing country with high shares of informality. Unlike the studies of developed countries (e.g., ons, 2020; Mongey \& Weinberg, 2020; Mongey et al., 2020, etc.), it focuses explicitly on characterising the informal sector (contrasting the results between the informal and formal workers) and how these interact with the occupational characteristics identified in the literature - unlike some studies of developing countries, such as Delaporte and Peña (2020) and Dingel and Neiman (2020). In addition, it examines the ability to work from home and the issues of individual proximity, but also the necessity of face-to-face working. The present work made several statistical and methodological interventions to improve the relatively poor-quality data, which often confounds statistical analyses for developing countries, particularly for the informal population. The study replaces the outdated Colombian occupational classification by recoding the raw (uncoded) occupational data to the most recent international occupation (ISCO-08) at a highly detailed occupational level (four-digit). As the use of $\mathrm{O}^{*}$ NET (Occupational Information Network) to identify the characteristics of jobs by occupation in developing economies has been widely debated, the present study uses both $\mathrm{O}^{*}$ NET and STEP (Skills Toward Employability and Productivity Survey) to identify the key characteristics of these four-digit occupations (that may make them more or less susceptible to transmitting the virus) to ensure the results are comparable.

Labour workforce information from the Colombian Household Survey -Gran Encuesta Integrada de Hogares (GEIH) - is utilised to identify the share of most exposed workers to covid-19 and social distancing effects. This survey collects information of 23000 households monthly, which allows Colombian populations' characteristics and employment structure to be fully characterised. Having this detailed occupational classification enables to directly measute a covid-19 occupational risk proximity index (Mongey et al. 2020) without using crosswalks or groupings and, thus, provides a more precise estimate. In order to quantify the possible effects of social distancing, work-from-home occupations are identified at the regional and sectoral levels, following Dingel and Neiman (2020), as well as an alternative measure proposed by Saltiel (2020) to compare the results.

First, we found that informal workers are less compatible with work-fromhome occupations and that sectors with the largest share of employment are less compatible with telework. Second, proximity affects more formal occupations, and proximity's affectation on informal employment is comparatively small when calculated using the index for face-to-face interaction. 
Personal and household characteristics are important to explain proximity and face-to-face. These findings suggest that the informal population is more vulnerable to the effects of social distance. This should raise policymakers' concerns since informal workers are already in a vulnerable population and, thus, the effects after confinement affect informal workers. Additionally, if measures are not or cannot be put in place to protect such workers, it may lead to an increase in informality. We found that the results from the $\mathrm{O}^{*} \mathrm{NET}$ and STEP lead to similar statistical estimates. This fact encourages the cautionary complimentary use of the $\mathrm{O}^{*} \mathrm{NET}$ as secondary data for analysis in developing countries.

This paper makes the following contributions. First, it provides evidence on the likely different effects of covid-19 in a developing country, Colombia, which exhibits the main characteristics of a dual economy. Second, this paper uses mixed methods, including machine learning techniques, to reallocate the raw household survey data to the latest international occupational classification, rather than relying on an outdated Colombian classification or using crosswalks. Third, it contributes to the ongoing debate on the suitability of $\mathrm{O}^{*} \mathrm{NET}$ in the context of identifying the characteristics of occupations in developing countries (Lo Bello et al., 2019). Specifically, results based on the us $\mathrm{O}^{*}$ NET are compared with those derived using STEP, which measures skills in low and middle-income countries. Fourth, unlike other studies, it utilises all three measures of exposure to risk which appear in the literature (teleworkability - the ability to work from home, individual proximity - whether the individual is required to work close to other workers, customers, etc. and the need for intensive face-to-face contact) and applies them to a developing rather than a developed economy. Finally, the paper provides evidence of links between covid-19 and informal employment, as well as personal and household characteristics that can provide a basis for informing government policies for different groups, including those most likely to benefit from covid-19 vaccines.

This document is divided into four parts. The first one presents the data. Next, it presents the methodology using labour workforce information from the Colombian Household Survey and which occupations are compatible with teleworking based on the work context and work activities dimensions from the $\mathrm{O}^{*}$ NET. After that, it reports a descriptive analysis of the share of work-from-home employment in the Colombian labour market at a national level and reveals which household and worker characteristics are more likely to be associated with teleworking. The last one is devoted to analysing, at a national level, the effect of proximity and face-to-face interactions. Analysing the latter is important because affected occupations (and populations) 
might see considerable changes in demand induced by changes in consumer behaviour to avoid contagion. Finally, it presents our conclusions and some remarks relevant to public policy.

\section{Data and descriptive statistics}

\subsection{Data}

The data used in this paper comes from the GEIH, which has been conducted since 2006 by the Colombian Statistics Office (DANE). The survey is designed to collect information on the Colombian population on a regular basis; thus, 23000 households are interviewed monthly. The questionnaire contains information at the worker and household level, including current level of education, age, occupation, sector, labour market, income, and household composition, amongst other characteristics.

DANE's (2009) guidelines are followed in establishing the composition of the Colombian labour force (working-age population) and determining the levels of informal employment. In Colombia, an individual belongs to the labour force if he/she is older than 10 years old in rural areas and 12 years or more in urban areas. A worker is a person who is in the working-age population and has either a formal or informal job. An informal employer is one that hires employees and workers based in private establishments, businesses, or companies that engage up to five people (in all their agencies and branches), including the owner or partner, unpaid family workers, domestic employees, and self-employed workers (except independent professionals). ${ }^{2}$ Following Colombian statistical guidelines, small firm size and informality are positively correlated with poor working conditions in small Latin American firms, including social security contributions and benefits.

In addition to the GEIH, international sources $\mathrm{O}^{*} \mathrm{NET}$ and STEP were used to map teleworking and high-proximity occupations. Specifically, $\mathrm{O}^{*} \mathrm{NET}$ is a us-based system that provides both up-to-date and detailed job descriptors for each occupation, including the knowledge, skills, and abilities required by workers, as well as how the work is performed in relation to tasks, and work activities and context, amongst other descriptors (Onetcenter, 2016). As will be discussed in the following sub-section, using the tasks associated with each occupation from this detailed database enables the occupations most compatible with teleworking and those involving working in close proximity with others to be determined.

2 Government employees are excluded from this definition. 
An alternative source of such data is provided by the World Bank, which has conducted cross-national and longitudinal surveys (STEP) to measure job descriptors in low- and middle-income countries. ${ }^{3}$ STEP includes information on characteristics, such as age, gender, and dwellings (e. g., kind and ownership status of dwellings) as well as household assets (e.g., televisions, computers, washing machines), etc. Moreover, a 15-64-year-old member of each household is randomly selected to provide detailed information about the nature of their employment, for example, about personality traits, behaviour, tasks performed at work (such as literacy and numeracy levels), use of computers, heavy machine handling, and other job characteristics. Importantly, the STEP registers information about each worker's occupation at a three-digit level under the harmonized International Standard Classification of Occupations 2008 (IsCO-08) (Pierre et al., 2014). Along with variables related to tasks performed at work, this occupational information is crucial because it allows the identification of groups of occupations whose tasks can be performed at home. Following Saltiel (2020), in the present study, the STEP information was restricted to workers who have been employed in the past twelve months. Given the lack of information about employment outcomes, unpaid family workers and people in the armed forces were omitted from the sample.

\subsection{Descriptive statistics}

The sample period runs from January 2016 to December 2019. The data are pooled to guarantee enough observations at the most detailed level of disaggregation (e. g., 4-digit occupations). Table A1 shows the general characteristics of the Colombian workforce in 2016-20194, ages 15-54 unless otherwise shown - the present discussion focuses on some of the more important features. The data are divided into three sets of rows:

Worker characteristics. According to the first column, $25.7 \%$ of Colombian workers are above 50 years old (the "older adult" category). The second and third columns indicate that, while only $16.3 \%$ of individuals in formal work are over 50 , this corresponds with $32.0 \%$ of informal workers, reflecting the

3 Armenia, Bolivia, Yunnan Province in China, Colombia, Georgia, Ghana, Kenya, Laos, Macedonia, and Vietnam.

4 'External immigrant' refers to foreign people living in the country. 'Internal immigrant' refers to Colombian people who have recently (within 5 years) moved to live in another city within the country. 'One year or more working' indicates the percentage of people that have been continuously working in the same job for one year or more. 
need for informal workers to continue earning. Males form $58.3 \%$ of the overall workforce, and the percentages of males are very similar for formal and informal workforces (56.7 and 54.1\%). Single individuals comprise 42.0 of the overall workforce; there is little difference between formal and informal workers (44.2 and $43 \%$, respectively). External immigrants only form $2.7 \%$ of the overall workforce, while internal immigrants (those who change location within Colombia) form $11.6 \%$, with a somewhat higher percentage of formal $(12.8 \%)$ than informal $(9.6 \%)$ workers - probably linked to moving location when obtaining a new job amongst the formal workforce. One of the largest differences between formal and informal workers is in educational attainment, with $44.3 \%$ of formal workers holding at least a college degree, ${ }^{5}$ while, in sharp contrast, the percentage of informal workers with at least a college degree is $11.4 \%$. This difference indicates that the informal sector is mostly composed of people with relatively low educational attainment.

Job characteristics. The occupational characteristics of the formal and informal sectors (shown in the second group of rows in table A1) are consistent with the wider literature, with informal workers (based on the firm size definition described above) generally more exposed to poorer and more vulnerable conditions. For instance, $64 \%$ of informal workers have an income below the national minimum wage (low-labour market income), compared with only $14.4 \%$ of formal workers. Informal workers are likely to be selfemployed or working in micro-establishments, while $67.4 \%$ of formal workers are located in enterprises with over 30 employees. Only $5.2 \%$ of informal workers, compared with $80.3 \%$ of formal workers, have a written contract, and a much higher proportion of informal workers are part-time $(46.8 \%)$, compared with their formal counterparts $(29.2 \%)$. The second part of the job characteristics rows gives the percentage distribution of individuals across sectors, broken down separately for formal and informal workers. While there are interesting differences across a range of sectors, two stand out in terms of their relative size and different compositions of formal and informal workers. The first is Wholesale, retail, etc. with $27.3 \%$ of all workers, comprised of $19.1 \%$ the formal and $39.9 \%$ of the informal workforces, which can be compared with Community, social, etc. with $19.6 \%$ of the total workforce, comprising $31.6 \%$ of the formal and $15.7 \%$ of the informal workforces respectively.

Household characteristics. Regarding household characteristics, the final set of rows in table A1 indicates large differences between formal and informal sectors for household income and Internet access. For instance, 35.8\%

5 Vocational training or a bachelors' degree. 
of informal workers live in households in which the household income per capita is below the national median, compared with $12.2 \%$ of formal workers. $41.0 \%$ of informal workers live in a household with Internet access, while this percentage is considerably higher for formal workers $(64.5 \%)^{6}$

The main point to take away from table A1 is that Colombia appears to be a classic example of a dual labour market, segmented to a considerable degree between formal and informal working (Piore, 2014; Bosworth, 1996, pp. 335-342), in which informal workers overwhelmingly work under poorer and more vulnerable conditions than their formal counterparts. Hence, due to the outbreak of covid-19 and social distancing measures, we might expect these conditions to have a higher impact on a labour market such as the Colombian one, where a considerable share of the workforce is composed of vulnerable, informal workers. The extend of this impact will depend on the share of informal/formal workers that cannot work remotely or require high proximity with others to perform their tasks. Consequently, one fundamental element to address the possible negative effects of covid-19 is the proper measurement of the proportion of workers that might be more affected by this pandemic which is addressed in the methodology set out below.

\section{Methodology}

As demonstrated in the previous section, the GEIH is a valuable source of information of worker, job, and household characteristics that distinguishes them by formal and informal workers. However, at the time of writing, individuals' occupations have been coded at the two-digit level, based upon the Colombian Standard Occupational Classification of 1970 (soc-1970). Obviously, much has happened to the nature and composition of occupations since 1970, which gives rise to at least two specific issues for the present analysis - the identification of teleworking or high-proximity occupations. For instance, a set of new occupations have emerged during the last few decades (e. g., Big Data analysts, app developers, etc.), and soc-1970 does not list the proper categories for grouping these occupations (Cárdenas, 2020). Second, soc-1970 does not identify unique occupational groups; for example, 'cooks, waiters, etc.' conform to occupational group 53 while 'food preparation workers: bakers, etc.' belong to group 77 , and these workers with similar

6 It is important to note that the informal/formal definition only applies to the urban zones of the country. For this reason, the national rates do not necessarily lie between the informal and formal rates. 
tasks can be allocated in different occupational groups. These two issues are crucial because current methodologies developed to measure teleworking and high-proximity occupations (Dingel \& Neiman, 2020; Mongey et al., 2020; Saltiel, 2020) rely heavily on up-to-date and disaggregated occupational classifications able to identify specific tasks performed by each worker.

One solution is to try to use crosswalks to recode soc-1970 to a more up-to-date occupational classification such as IsCO-08 (provided by ILO). However, the relevance of crosswalks that span the period between soc-1970 and Isco-08 is limited; for example, the 2-digit soc-1970 includes the occupational group 'Building keeper, doorman, sacristan, cleaner, window cleaner, chimney sweep' (code 55), the components of which belong to different occupational groups in Isco-08. A building keeper, in Isco-08, is coded as 'Security guards' (code 54 at a 2-digit level) while a cleaner is coded as 'Domestic cleaners' (code 91). Consequently, an attempt to map soc-1970 to Isco-08 occupational groups is likely to result in considerable inaccuracies. These measurement errors are relevant for the estimation of teleworkable or high-proximity occupations since one occupation in the same occupational group, for instance, might require high proximity with others while the opposite can be true for other occupations in the same category at a 2-digit level.

The present work overcomes these issues by utilising an interesting feature from the GEIH, namely the availability of individuals' raw occupational responses. Access to this raw text provides a means of reclassifying the information to ISCO-08 and SOC-ONET ${ }^{8}$ at 4-digit and 6-digit levels (avoiding the use of crosswalks). This is carried out using a mixed method approach which includes machine-learning techniques to code text responses to IsCO at a 4-digit level (Cárdenas, 2020). First, to ensure that the most frequent job titles ${ }^{9}$ were properly coded, a manual coding process was conducted for the most frequent responses. By performing this manual codification, it was possible to code around $40 \%$ of the observations in the GEIH. To classify the remaining job titles, a "nearest neighbour algorithm" was conducted as the literature suggests this form of the algorithm provides higher accuracy when coding job titles than other algorithms (Gweon et al., 2017). A training database to test the method was constructed using a list of around 600000 occupational

7 To the extent of our knowledge, an official crosswalk does not exist between soc-1970 and Isco-08 due to the limitations of using crosswalks between these two classifications.

8 https://www.onetcenter.org/taxonomy.html

9 For instance, three of the most frequent job titles are 'call center operators', 'market sales workers', and 'Bricklayers'. 
titles from the GEIH and sources such as job portals - pre-classified at a 4-digit Isco level and validated (Cárdenas, 2020). ${ }^{10}$

The codification at a 4-digit level is important because it enabled different international classifications (e. g., $\mathrm{O}^{*} \mathrm{NET}$ ) to be merged to the Colombian data with greater precision. In particular, the use of international classifications at a 3-digit level or lower results in increasingly less precision in the categorisation of telework or high-proximity occupations. For instance, in Isco-08, the category 'Client information workers' (code 422) occurs at a 3-digit level, which includes the subgroups 'Telephone switchboard operators' (code 4222) and 'Hotel receptionists' (code 4224). It is likely that 'Telephone switchboard operators' is a teleworkable occupation, but 'Hotel receptionists' is not. ${ }^{11}$ This was checked by comparing the 4- and 2-digit Isco levels, ${ }^{12}$ which indicated that for $13.4 \%$ of workers, the same methodology categorised them in a different group (e. g., non-teleworkable versus teleworkable), with a similar disparity for high proximity categorisation of around $11 \%$. Moreover, this disparity level is expected to rise when crosswalks (e. g., soc-1970 to Isco-08) are used, given the limitations of this procedure mentioned previously. Thus, the present methodology provides more precise results because it allows the analysis of the GEIH at the 4-digit level, allowing the household data to be combined with other sources ( $\mathrm{O}^{*} \mathrm{NET}$ and STEP) to determine the proportion of workers susceptible to distress due to the covid-19 pandemic.

To measure to what extent an occupation is teleworkable, we follow Dingel and Neiman (2020), who determine which occupations are compatible with teleworking based on the work context and work activities dimensions from $\mathrm{O}^{*}$ NET. Using $\mathrm{O}^{*}$ NET in developing countries has been a cause of concern in research given the differences in working realities between the developed and developing world, including differences in technology adoption, occupation licensing and legislation, and the prevalence of informal work in developing countries. To address this issue, the analysis compared the results using both $\mathrm{O}^{*}$ NET and STEP. Following the work on developing countries

10 A manual check was conducted to determine the accuracy of correctly coded observations. Based on this manual check, around $91 \%$ of observations had the correct occupational code (ISCO) at a 4-digit level. Additionally, common mistakes were manually corrected.

11 The role includes check-in and check-out tasks which require some on-site work, although taking phone reservations could be performed remotely.

12 We merged the $\mathrm{O}^{*}$ NET (6-digits level) and the ISCO (4-digits level) classifications. We assumed that if an occupational group at 2-digit Isco level is mostly composed of teleworkable or high proximity occupations according to the $\mathrm{O}^{*} \mathrm{NET}$ (more than $50 \%$ ), this group at 2-digit Isco level is coded as teleworkable or high proximity. 
by Saltiel (2020), a teleworkable indicator at the 4-digit occupational level is calculated using the STEP survey, ${ }^{13}$ with all countries pooled. ${ }^{14}$ With this alternative measure, the analysis tests of $\mathrm{O}^{*} \mathrm{NET}^{\prime} \mathrm{s}$ rich source of information produces consistent results when it was adapted to the Colombian case. The next section reports on the estimates for each of the teleworkable indicators. Considering that technology penetration is lower in Colombia, ${ }^{15}$ these estimates are probably an upper limit (an optimistic scenario) for teleworkcompatible occupations, at least in the case of $\mathrm{O}^{*}$ NET. The share of workers in teleworkable occupations reported is also in line with the country level reported in Dingel and Neiman (2020).

To measure workers that are at higher risk of covid-19 contagion because they work in close proximity with others, a proximity index was calculated following Leibovici et al. (2020) ${ }^{16}$ and Mongey and Weinberg (2020). The proximity index indicates if an occupation needs to be performed at a proximity of 1.5 metres or less (less than an arm's length). ${ }^{17}$ Since there is not a comparable measure in the sTEP survey, only the results from the $\mathrm{O}^{*}$ NET index are presented. As earlier, a similar disclaimer as above can be made, as these estimates are likely to be lower bound (e. g., an optimistic scenario) due to cultural differences and institutional arrangements (e. g., occupational licensing, health and safety regulations). Identifying the share of individuals in occupations that require high proximity is a result of both supply and demand factors: workers try to avoid supplying their labour to high-risk occupations; people become reluctant to buy goods and services where personal proximity is high to avoid contagion.

Finally, following Avdiu and Nayyar (2020), an index was constructed indicating whether the person performing the occupation requires faceto-face contact in their work. This information also comes from the $\mathrm{O}^{*} \mathrm{NET}$

13 The index is composed of the following dimensions: (i) Lifted Anything more than 50 Pounds; (ii) Time/contact involved with non-coworkers/customers; (iii) Repair electronic equipment (already generated); (iv) Operate/work with heavy machines (already generated); (v) Use a computer at work. The results are then aggregated to Isco-08 3-digit level and merged with the GEIH.

14 We used all 16 countries, excluding China and Albania, and did not only consider the information on Colombia because the sample size is small (1930 observations).

15 For instance, as reported by OECD (2019), Colombia has one of the lowest broadband penetration rates in OECD countries.

16 Leibovici et al. (2020) propose a similar indicator to evaluate covID-19 impact based on proximity, to ISCO-08 4-digits and SOC-ONET at a 6-digit level.

17 Category 4.C.2.a.3 from the $\mathrm{O}^{*} \mathrm{NET}$, Work Context. 
taxonomy. ${ }^{18}$ An indicator function was constructed reflecting the degree of face-to-face contact, from which an index assigned a value of one if the occupation lay above the seventy-fifth percentile of the distribution and zero otherwise. This alternative measure enables a complete picture of the share of workers that might be more affected by the covid-19 outbreak due to close proximity.

\section{Teleworking and Employment Type}

In this section, we describe the results for occupations that are compatible with teleworking. According to the results constructed from the $\mathrm{O}^{*} \mathrm{NET}$ data (Table 1), ${ }^{19}$ one-fifth of occupations in Colombia can potentially be performed remotely (around 4.5 million people out of 22.8 million). However, just $13 \%$ of the informal population can perform their occupations remotely, compared to $35 \%$ of the formal population. The corresponding results from the STEP survey are similar to the $\mathrm{O}^{*} \mathrm{NET}$ based estimates, suggesting that the percentage of occupations that can be performed at home (e. g., are compatible with teleworking) comprise around $23 \%$ of all occupations, although this falls to only $10 \%$ amongst informal workers and rises to $48 \%$ of formal workers' occupations.

Table 1. Share of Workers in Occupations Compatible with Teleworking, Colombia

\begin{tabular}{lcccccc}
\hline & \multicolumn{3}{c}{ O*NET } & \multicolumn{3}{c}{ STEP } \\
\cline { 2 - 7 } & National & Formal & Informal & National & Formal & Informal \\
\hline Teleworkable occupations & $19.7 \%$ & $35.4 \%$ & $13.4 \%$ & $22.7 \%$ & $48.8 \%$ & $10.3 \%$ \\
Non-teleworkable occupations & $80.3 \%$ & $64.0 \%$ & $86.6 \%$ & $77.3 \%$ & $51.2 \%$ & $89.7 \%$ \\
& $100.0 \%$ & $100.0 \%$ & $100.0 \%$ & $100.0 \%$ & $100.0 \%$ & $100.0 \%$ \\
\hline
\end{tabular}

Source: Own calculations based on DANE-GEIH, 2016-2019.

Table 2 shows a comparison of the estimated proportions of teleworkable occupations for Colombia based on $\mathrm{O}^{*} \mathrm{NET}$, using the task content of us occupations and STEP, based on Colombian tasks information. The results

18 This construction is based on the work context 4.C.1.a.2.l, which relates to the frequency in which a person requires face-to-face discussions to perform his/her job. A higher value means that face-to-face interactions are more frequent.

19 It is important to note that the numbers at the national level include urban and rural zones, while formal/informal numbers (as previously mentioned) only include urban zones. For this reason, the percentage at the national might be less than the informal and formal numbers. This issue is also present in tables 2, 3, 4 and 5. 
show that both methods coincided with $84.3 \%(70.9 \%+13.4 \%)$ of their occupational task classifications for workers in Colombia.

Table 2. O*NET and STEP Comparison of the Proportion of Workers in Teleworkable Occupations, Colombia

\begin{tabular}{llcc}
\hline & \multicolumn{2}{c}{ STEP } \\
\cline { 3 - 4 } & & Teleworkable occupations & $\begin{array}{c}\text { Non-teleworkable } \\
\text { occupations }\end{array}$ \\
\hline \multirow{2}{*}{$\mathrm{O}^{*} \mathrm{NET}$} & Teleworkable occupations & $70.9 \%$ & $9.3 \%$ \\
& Non-teleworkable occupations & $6.2 \%$ & $13.4 \%$ \\
\hline
\end{tabular}

Source: Saltiel (2020) and own-calculations.

The differences between the percentages presented in this paper for Colombia and the ones indicated by Saltiel (2020) are likely to arise from differences in the data used in the analyses. Delaporte and Pena (2020) report that the Saltiel (2020) STEP measure always falls below the corresponding $\mathrm{O}^{*} \mathrm{NET}$, whereas Table 1 of this paper has a STEP measure greater than the O*NET measure $(22.7 \%$ compared with $19.7 \%$ respectively). There are incompatibilities between all three sources (Delaporte \& Peña, 2020; Saltiel, 2020; the present study).

The first differences in the data come from the fact that Saltiel (2020) used the STEP survey - rather than the GEIH - looking for it to be representative for non-institutionalised people from 15 to 64 years of age, living in private dwellings in just thirteen major Colombian urban areas using 2012 data and comprising a sample of only 9960 individuals (Pierre et al., 2014). As outlined above, the present study uses the GEIH, which is representative at the national level (rural and urban areas), covering around 23000 households monthly from 2016 to 2019.

Second, Delaporte and Peña (2020) used crosswalks and the 2-digit level soc-1970 to identify the share of workers in work-from-home occupations. As discussed above, this way of estimating the share of teleworkable occupations is likely to be imprecise given the presence of measurement errors from difficulties of linking to dated occupational categories and the issues of working at a much higher level of occupational aggregation. Moreover, it seems that Delaporte and Pena (2020) do not consider Antioquia (one of the largest counties in Colombia) in their estimates.

Consequently, the data and methodology adopted in this study are more likely to be precise in measuring the share of workers in potentially work-from-home occupations. Furthermore, although the teleworkable occupational shares here are below Dingel and Neiman's (2020) estimates for 
the us $(37 \%)$, the percentage for Colombia is in line with estimates for other Latin American countries (Bolivia 15\%, Chile $25 \%$ ) and developing economies more generally. These results suggest that the present calculations are a reasonable description of the Colombian labour market and consistent with the main message holds: a substantially higher proportion of formal workers can potentially continue to work from home, while informal workers are in a considerably more disadvantaged position.

\subsection{Households and Workers Characteristics in Teleworkable Occupations}

Table 3 shows the distribution by sector, based upon the proportion of workers in teleworkable occupations in each sector: three sectors (Agriculture and Construction, for short, and to a lesser extent Transport) seem to be the least compatible with teleworking; the two sectors most compatible with teleworking are Financial intermediation and Community, etc., followed by Electricity, etc. In most sectors, formal workers tend to work in occupations more compatible with teleworking compared to informal workers, with Electricity, etc., and financial intermediation the exceptions.

Table 3. Share of Workers in Occupations Compatible with Teleworking by Sector, Colombia

\begin{tabular}{lccc}
\hline \multicolumn{1}{c}{ Sector } & Total national & Formal & Informal \\
\hline Agriculture, hunting and forestry & $2.1 \%$ & $13.0 \%$ & $1.3 \%$ \\
Mining and quarrying & $16.7 \%$ & $24.7 \%$ & $5.4 \%$ \\
Manufacturing & $15.4 \%$ & $25.0 \%$ & $6.4 \%$ \\
Electricity, gas, and water supply & $33.6 \%$ & $35.0 \%$ & $44.0 \%$ \\
Construction & $8.1 \%$ & $19.5 \%$ & $2.8 \%$ \\
Wholesale, retail trade, hotels, and restaurants & $19.7 \%$ & $24.0 \%$ & $18.1 \%$ \\
Transport, storage, and communications & $13.7 \%$ & $28.8 \%$ & $8.0 \%$ \\
Financial intermediation & $64.1 \%$ & $62.3 \%$ & $76.7 \%$ \\
Real estate, renting, and business activities & $27.7 \%$ & $38.8 \%$ & $11.9 \%$ \\
Community, social, and personal service activities & $37.1 \%$ & $49.8 \%$ & $17.9 \%$ \\
\hline
\end{tabular}

Source: Own calculations based on DANE-GEIH 2016-2019.

Figure A1 plots the distribution of teleworking occupations by region. The map reveals that the proportions of workers in teleworkable occupations 
are generally relatively low. Although, some regions have considerably lower rates, such as Boyacá, Huila, and Magdalena, whose shares of workers in teleworking occupations are between $7.3 \%$ and $13.8 \%$. However, for the richer regions, such as Bogotá (Colombia's capital) and Antioquia, this percentage is somewhat higher, between $20.1 \%$ and $28.3 \%$. The results suggest that no one region has an occupational structure compatible with high levels of teleworking.

This situation is more acute for informal workers, regardless of the sector they work in, indicating that, in general, these workers perform activities that are not compatible with teleworking. Consequently, a considerable share of workers in developing economies with relatively high informality rates (such as Colombia) are unable to telework. They face an unenviable decision as to whether to continue working and have a higher risk of contracting COVID-19 or to stop working, reducing their risk of contagion, but experience worsening living conditions. This dilemma makes the decision to implement social distancing measures more difficult in countries with high informality rates, such as Colombia.

One of the main objectives of the present document is to identify the characteristics of workers within the population that face for which this dilemma is critical and would be placed under significant stress from social distancing measures. To distinguish such differences, the discussion focuses on (i) demographic characteristics, such as age, sex, marital status, immigration status, and education level; (ii) household characteristics, including household location, internet connectivity, household composition, and household income level, and (iii) the work component, considering variables such as individual income, firm size, the amount of experience in the firm, and last the legal aspects of the employment relationship.

To estimate the relationship between such factors and teleworkability, dummy indicators were constructed for each of the characteristics and for teleworkability, as described below. Following Mongey and Weinberg (2020), ${ }^{20}$ the 0.1 indicator for each characteristic is then regressed in turn on the workfrom-home (teleworkable) dummy to construe the partial links between the two. Consequently, to provide a more detailed characterisation of workers in work-from-home occupations, equation (1) was estimated:

$$
y i=\beta X i+\varepsilon
$$

20 Note that analogous results are obtained if $X i=\beta y T W, i+\varepsilon i$ is used rather than the form of equation (1), but the results estimate $1 / \beta$ rather than $\beta$. 
Where $y i$ takes values of 1 if, for instance: the $\mathrm{i}^{\text {th }}$ worker's income is below the national average (low-labour market income) and zero otherwise; (or) it takes a value of 1 if the worker has a college degree and zero otherwise, etc. Likewise, $X_{i}=1$ indicates if the person, $\mathrm{i}$, works in a teleworkable occupation ( $X=0$ otherwise). Consequently, $\beta$ shows the portion of workers who are in teleworkable occupations for the two different population groups (low or high income and lowly or highly qualified, etc.), as reported in Figure 1. The results from equation (1) are just a simple way of summarising the underlying statistical link between teleworkability and each of the population characteristics (listed in table A1) but do not identify causal relationships.

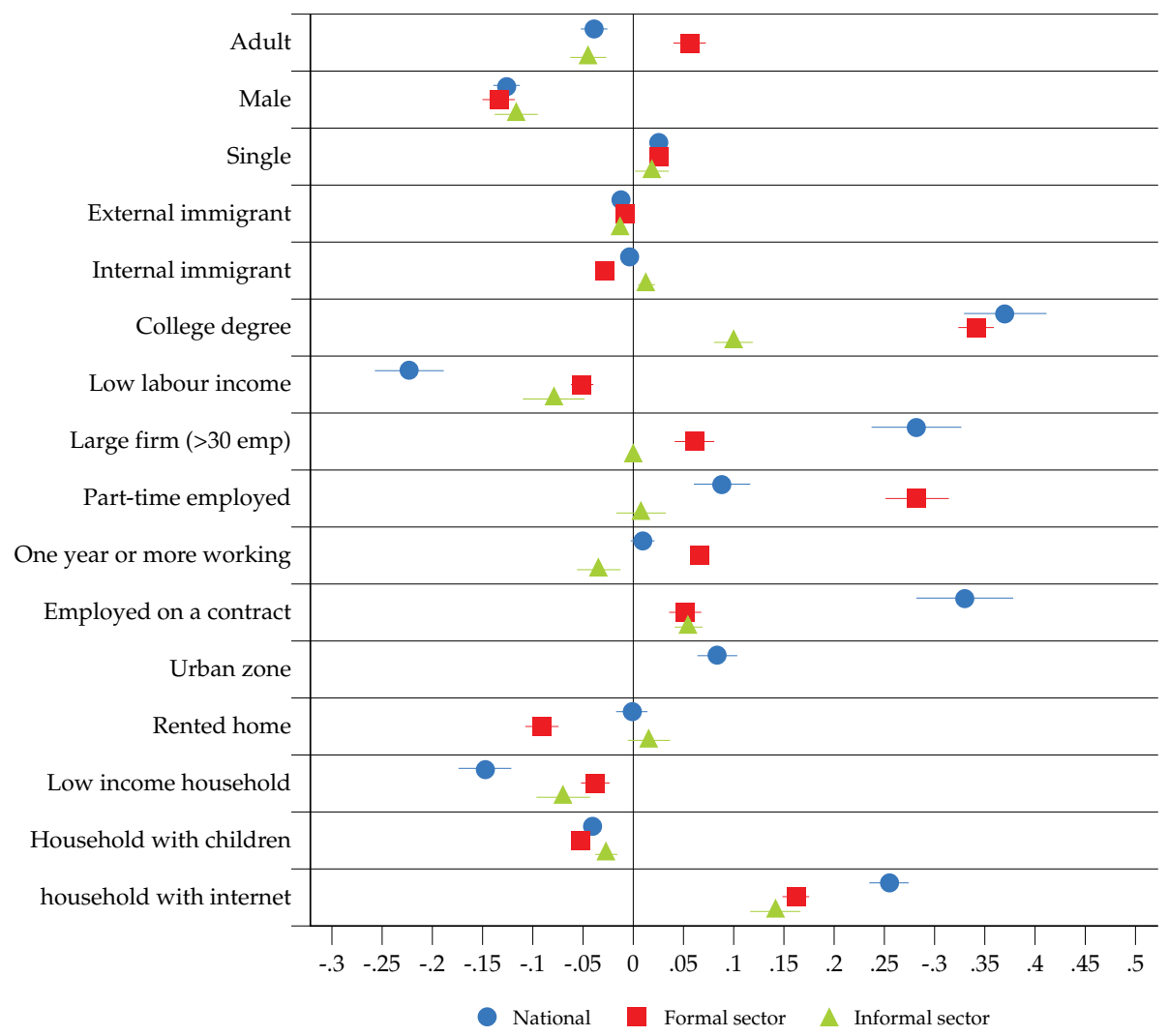

Figure 1. Proportions of formal and informal workers in teleworkable occupations by individual worker characteristics

Source: Own calculations based on DANE-GEIH 2016-2019.

One of the advantages of using the GEIH is that it is possible to distinguish the empirical links between the proportion of teleworking and specific 
dimensions for the formal and informal populations. ${ }^{21}$ This allows the analysis to focus on the differences in the characteristics of formal and informal workers that place one or another group in a more invidious position when faced with the effects of covid-19, as shown in figure 1. Each dot in the figure represents a proportion associated with each characteristic of interest for each of the three population groups, resulting from equation estimation (1). For example, at a national level, the portion of people in work-from-home occupations with low-labour income is 22.3 percentage points lower than those in non-teleworkable occupations with a low-labour income. This result suggests that the share of low-labour income workers is relatively higher for non-teleworkable occupations. A similar pattern can be observed for both formal and informal workers, suggesting that the share of low-labour income workers is relatively higher for non-teleworkable occupations regardless of informal/formal status.

In contrast, the portion of workers in work-from-home occupations with an Internet connection at home is almost 30 percentage points higher than those in non-teleworkable occupations with an Internet connection at home. Overall, these results confirm that vulnerable workers (especially in terms of income) tend to have a lower probability of being in a work-from-home occupation.

\subsection{Likelihood of Having a Teleworkable Occupation}

The above results presented an initial, descriptive analysis of the share of work-from-home employment in the Colombian labour market. This section extends these results by adopting a multivariate analysis of the characteristics that make a person less or more likely to be able to work remotely (see Table A2 for details). The results of this estimation may provide a starting point from which the government could focus its actions on the variables that have more significant effects on workers' probability of working remotely.

In what follows, the econometric estimation follows Saltiel (2020) to compare his findings for a developing country and the present estimates using $\mathrm{O}^{*} \mathrm{NET}$ on the Colombian data. This analysis differs from the model presented above by Mongey and Weinberg (2020), in which the observables are at the left-hand side, and the work-from-home index is the covariate. Hence, to calculate the likelihood of workers being employed in work-fromhome occupations, the following regression was adopted:

21 Informality is measured only at the urban level, so it is not possible to assess if economic activities in rural areas are associated with telework. 


$$
I_{i}=\beta Z_{i}+D_{R, i}+D_{S, i}+\in
$$

Where $I i$ is the teleworkable indicator for the $\mathrm{i}^{\text {th }}$ individual, $\mathrm{Z}$ is a set of covariates that characterise the workers and their households, and $D_{k}$ is a set of regional and sectoral dummies. In order to identify possible effects of informality within the population, three sets of regressions were again estimated: at the national level, with formal workers, and containing informal workers.

Figure 2 reports the results of the estimation. ${ }^{22}$ Over the employed population as a whole, the following characteristics considerably increase the likelihood of having a teleworkable occupation: a college degree, being employed on a contract, and living in a house with Internet access. ${ }^{23}$ On the other hand, being an external immigrant with a low-labour income decreases an individual's probability of having a work-from-home occupation.

However, the magnitude of some of these coefficients varies depending on whether the worker is in the informal sector or not. First, for example, the most important difference is associated with whether the individual has a college degree. In the national sample, having a college degree raises the likelihood of having a teleworkable occupation by $18.9 \%$, a value that is in line with Saltiel's (2020) findings but considerably less than the estimates for the us economy (Dingel \& Neiman, 2020). Nevertheless, when considering the informal workforce, while holding a college degree still remains significantly positive (5.9\%), it is around one-third of the estimated national level value even lower than the value for formal workers, at around $21 \%$. Second, parttime employment is another variable for which effects in the informal-formal workforce differ. While part-time employment has a significant all-worker coefficient of $7.4 \%$ and, for formal workers, contributes more substantially to the likelihood of teleworkability (20.3\%), for the informal population, it bears no importance. In general, part-time jobs are more compatible with teleworking. However, part-time workers in the formal sector tend to have a higher probability of having a teleworkable job than part-time workers in the informal sector. Third, being older (adult) lowers the likelihood of possessing a work-from-home occupation, while the opposite is valid for a formal worker. Consequently, the three points above confirm that, after controlling

22 The estimates identify effects by region and sector. When introducing the occupation dummy the effect disappears since the index is constructed at the occupational level.

23 Only $42.9 \%$ of workers live in a house with an Internet connection (see Table A1). 
for individual and household characteristics, vulnerable people (such as less educated, older informal workers, etc.) are less likely to work remotely.

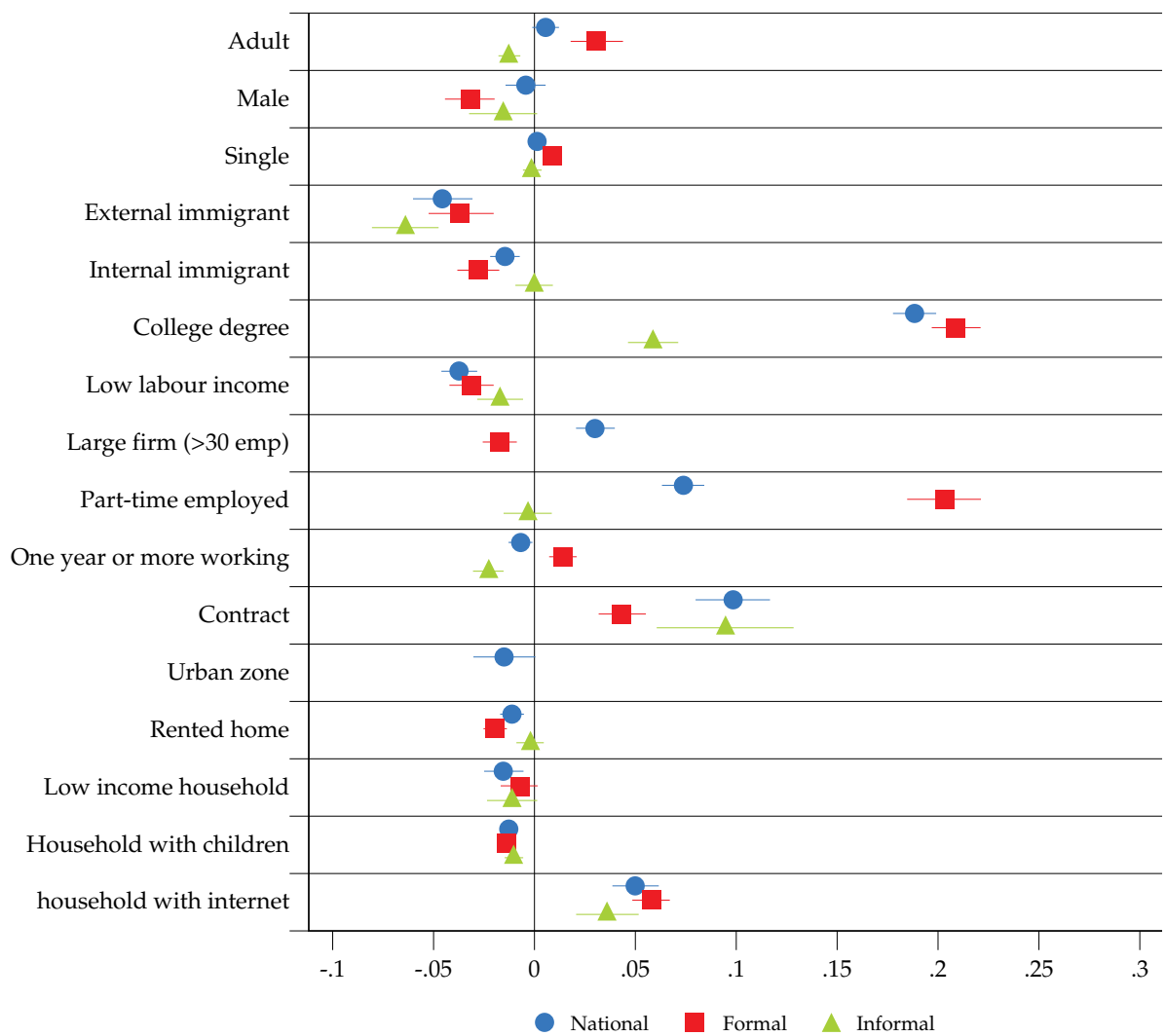

Figure 2. Likelihood of Working in a Teleworkable Occupation, by Personal Characteristics, Formal and Informal Work Source: Own calculation based on DANE-GEIH 2016-2019.

\section{High-proximity occupations and employment type}

It is difficult to talk about country-wide restrictions arising from the covID-19 outbreak in Colombia, as these can differ by department and city. ${ }^{24}$ However, a more general, if piecemeal, easing of social distancing measures increases the dilemma associated with the decisions about working amongst people in high-proximity occupations? While the removal of social distancing measures would alleviate the pressure for occupations that cannot work

24 https://co.usembassy.gov/covid-19-information/ 
remotely, returning to workplaces puts greater pressure on other occupations that require proximity or face-to-face interaction with clients or other workers. This section considers the magnitude and nature of the problems faced by such occupations.

To identify the magnitude of such effects, we made use of two different indexes: First, the proximity index of Mongey and Weinberg (2020), which identifies occupations requiring an arm's length, or less, of distance (1.5 meters or less); second, a face-to-face index following Avdiu and Nayyar (2020), which presents the share of individuals in occupations that require face-to-face interaction to be performed (see next section for more details).

\subsection{Household and Worker Characteristics in High-Proximity Occupations}

Table 4 shows the results of the proximity index: nationally, $10.6 \%$ of individuals (around 2.2 million people) work in high-proximity occupations; the figure is slightly larger for formal workers $(13.4 \%)$ and lower for informal workers $(10.8 \%)$. As noted before, the informal/formal definition only applies to the urban zones of the country. For this reason, the national rates (e.g., share of workers in high personal-proximity occupations) do not necessarily lay between the informality and formality rates.

Table 4. Share of workers in high personal-proximity occupations

\begin{tabular}{lccc}
\hline & National & Formal & Informal \\
\hline Non-high proximity & $89.4 \%$ & $86.6 \%$ & $89.2 \%$ \\
High-proximity & $10.6 \%$ & $13.4 \%$ & $10.8 \%$ \\
\hline
\end{tabular}

Source: Own calculations based on DANE-GEIH 2016-2019.

As in the case of work-from-home occupations, the distribution across regions for high-proximity occupations is heterogeneous, but there are some notable differences between the two measures (Figure A2). Regional disparities correlate with population density and regional sector composition. For instance, in high-density regions such as Bogotá (around 7.4 million inhabitants), Antioquia (6.4 million inhabitants), and Valle del Cauca (4.5 million inhabitants) the share of workers in high-proximity occupations is between $20.1 \%$ and $28.3 \%$, while in regions such as Huila (1.8 million inhabitants), Magdalena (1.3 million inhabitants), and Quindío (539904 inhabitants) the share of workers in high-proximity occupations is between $7.3 \%$ and $13.8 \%$. However, regions such as the Caribbean coast (north-west of the country) 
tend to be composed of a higher portion of people in high-proximity occupations (see Figure A2) compared with other regions. In contrast, the percentage of people in teleworkable occupations on the Caribbean coast is not relatively high (see Figure A1). As mentioned before, these differences are due to the population/sectorial composition of each region. For instance, it is well-known that the Caribbean coast has a considerable concentration on tourism activities. Most of these activities (such as tourist guides, lifeguards, etc.) require high proximity to others.

There are also wide variations in the incidence of close-proximity working across sectors (Table 5). Some sectors with a higher share of workers in highproximity occupations are also strategic sectors for employment in Colombia: Construction and Community, social, etc. are two sectors that strategically have been prioritised exiting quarantine (Presidencia de la República, 2020). The risk of performing occupations in such sectors should be taken into consideration, given the low options for informal workers that push them to work. Construction, in particular, has a very large difference between the proportion of individuals exposed to the virus because of face-to-face working in the informal and formal sectors ( $44.7 \%$ compared with $28.9 \%$ ).

Table 5. Share of Workers in High Personal-Proximity Occupations by Sector

\begin{tabular}{lccc}
\hline \multicolumn{1}{c}{ Sector } & National total & Formal & Informal \\
\hline Agriculture, hunting, and forestry & $2.5 \%$ & $6.9 \%$ & $2.3 \%$ \\
Mining and quarrying & $7.9 \%$ & $8.7 \%$ & $2.5 \%$ \\
Manufacturing & $6.9 \%$ & $5.4 \%$ & $9.0 \%$ \\
Electricity, gas, and water supply & $11.4 \%$ & $10.6 \%$ & $6.9 \%$ \\
Construction & $40.4 \%$ & $28.9 \%$ & $44.7 \%$ \\
Wholesale, retail trade, hotels, and restaurants & $3.5 \%$ & $5.4 \%$ & $2.9 \%$ \\
Transport, storage, and communications & $3.1 \%$ & $6.2 \%$ & $1.9 \%$ \\
Financial intermediation & $8.6 \%$ & $9.6 \%$ & $1.2 \%$ \\
Real estate, renting, and business activities & $14.9 \%$ & $18.1 \%$ & $10.0 \%$ \\
Community, social, and personal service activities & $20.1 \%$ & $22.4 \%$ & $26.2 \%$ \\
\hline
\end{tabular}

Source: Own calculations based on DANE-GEIH 2016-2019.

Again, equation (1) was used to provide some descriptive statistics of how the different characteristics of workers influence their exposure within high-proximity occupations (Figure 3). What is striking is that there are some important differences between the risks of exposure to coviD-19 for 
certain characteristics between the results for teleworkability (Figure 2) and proximity (Figure 3). At a national level, for instance, the portion of people in high-proximity - high risk- occupations with low-labour income was around 4.7 points lower than those with high-labour income, while the corresponding proportion with access to work-from-home jobs was $22.3 \%$ lower for those on low compared with high-incomes. Likewise, those with a college degree have more or less the same exposure from close proximity working as those with lower qualifications but have a $37.0 \%$ higher chance of being in a teleworkable occupation. On the other hand, those working in an urban zone have a higher access to teleworking $(8.4 \%)$, but also a higher exposure to close proximity ( $6.2 \%)$ than those in non-urban zones. Overall, these results are much less consistent with the hypothesis that vulnerable workers are more exposed to the virus from being in high-proximity occupations (low-income, low-educated workers, etc.). In particular, low-income

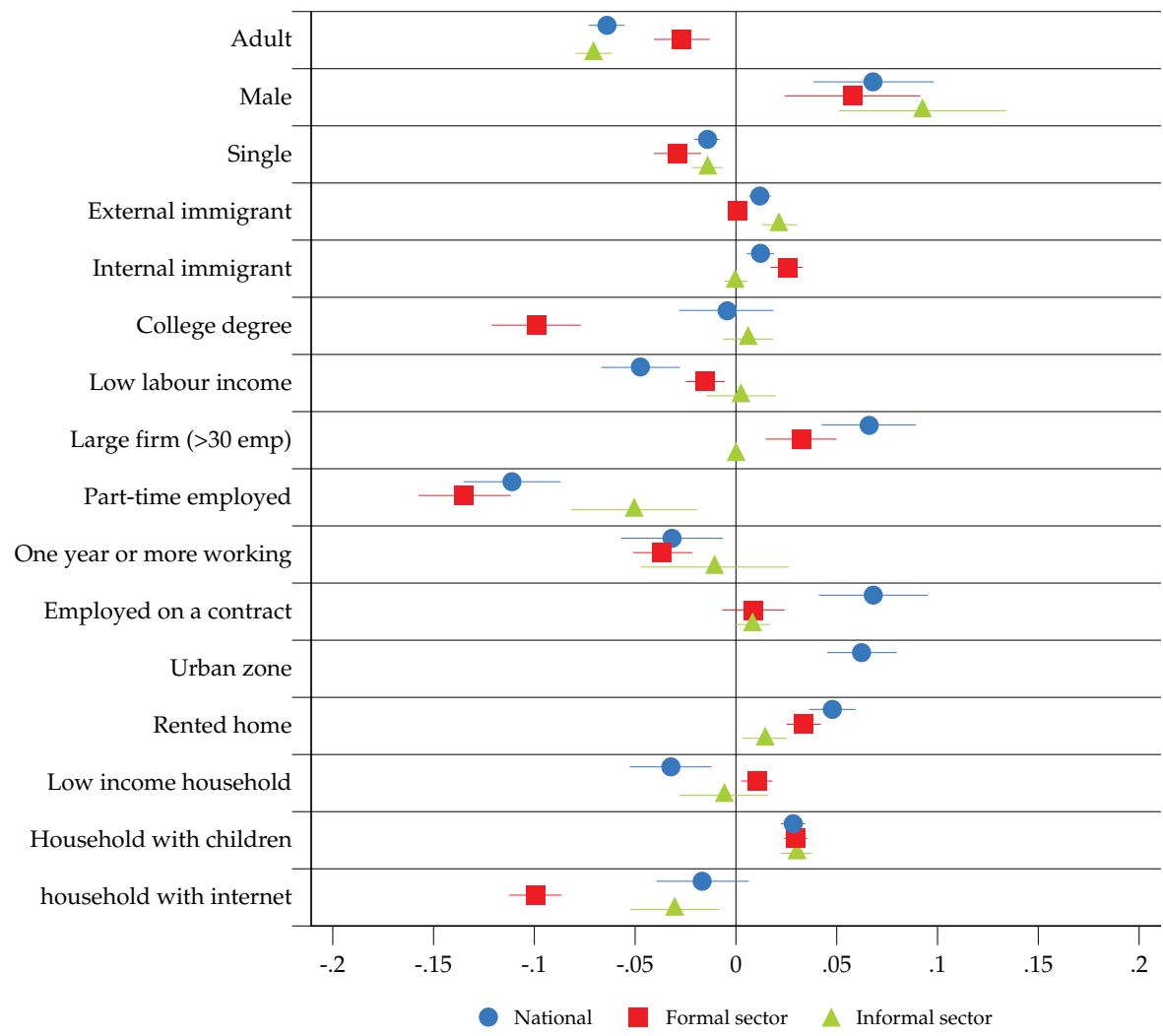

Figure 3. Characteristics of Workers in High-Proximity Occupations, by Job Type (Formal/Informal)

Source: Own calculations based on DANE-GEIH 2016-2019. 
individuals, low-income households, and part-time workers all have significant negative coefficients (lower exposure), while the college coefficient is not significantly different from zero.

While overall, there is less evidence across personal characteristics that the more vulnerable are more exposed to risk from close-proximity, there is still tentative evidence that informal workers are more at risk than formal workers. In the key personal characteristics of low-income, low qualifications, and part-time working, for example, the probabilities of working in close-proximity to other individuals are all lower for formal than informal workers ( 0.2 versus $1.5 \%, 0.6$ versus $9.9 \%$ and -5.1 and $-.13 .5 \%$, respectively). Having Internet access improves the outcome for both groups, though more for the formal than the informal workers ( 9.9 and $3.0 \%$, respectively). However, the reverse is true for some of the other characteristics, such as working in a large firm (3.2 versus $0.0 \%$ ) and living in rented accommodation (3.4 compared with $1.4 \%$ ).

\subsection{Likelihood of Having a High-Proximity Occupation}

Following equation (2), the likelihood of working in a high personal-proximity occupation is also estimated using multivariate analysis, and the results are set out in Table A3. The likelihood of being in a high-proximity occupation is regressed on largely the same set of variables as for teleworkable occupations, such as education, income, and part-time work, but also internet access (see Figure 4).

The main results are largely consistent with the partial regressions, but there are some important differences. In particular, being male is, again, significant positive $(2.2 \%)$ and being single is now significant negative $(-0.8 \%)$, and both of these results hold for the formal and informal work, with similar coefficients for the two types of work. Being an external migrant has a significant positive coefficient which, as in the partial results $(4.4 \%)$, can be traced to the results for informal workers (6.1\%). Having a college degree is now significant positive overall $(4.0 \%)$, but, as in the partial results, this can be traced to the formal workers, where the coefficient is now $6.6 \%$ compared with $2.5 \%$ for informal workers. Low labour income now carries an insignificant coefficient, with no difference between formal and informal workers, which is not dissimilar to the earlier results. Working in a large firm is an inconsistent result, now taking a small but significant negative coefficient (1.1\%), compared with the partial estimate of $6.6 \%$. Part-time working is again significantly negative $(-4.5 \%)$, traceable to the formal economy. One year of working now has a marginally positive but insignificant coefficient, 


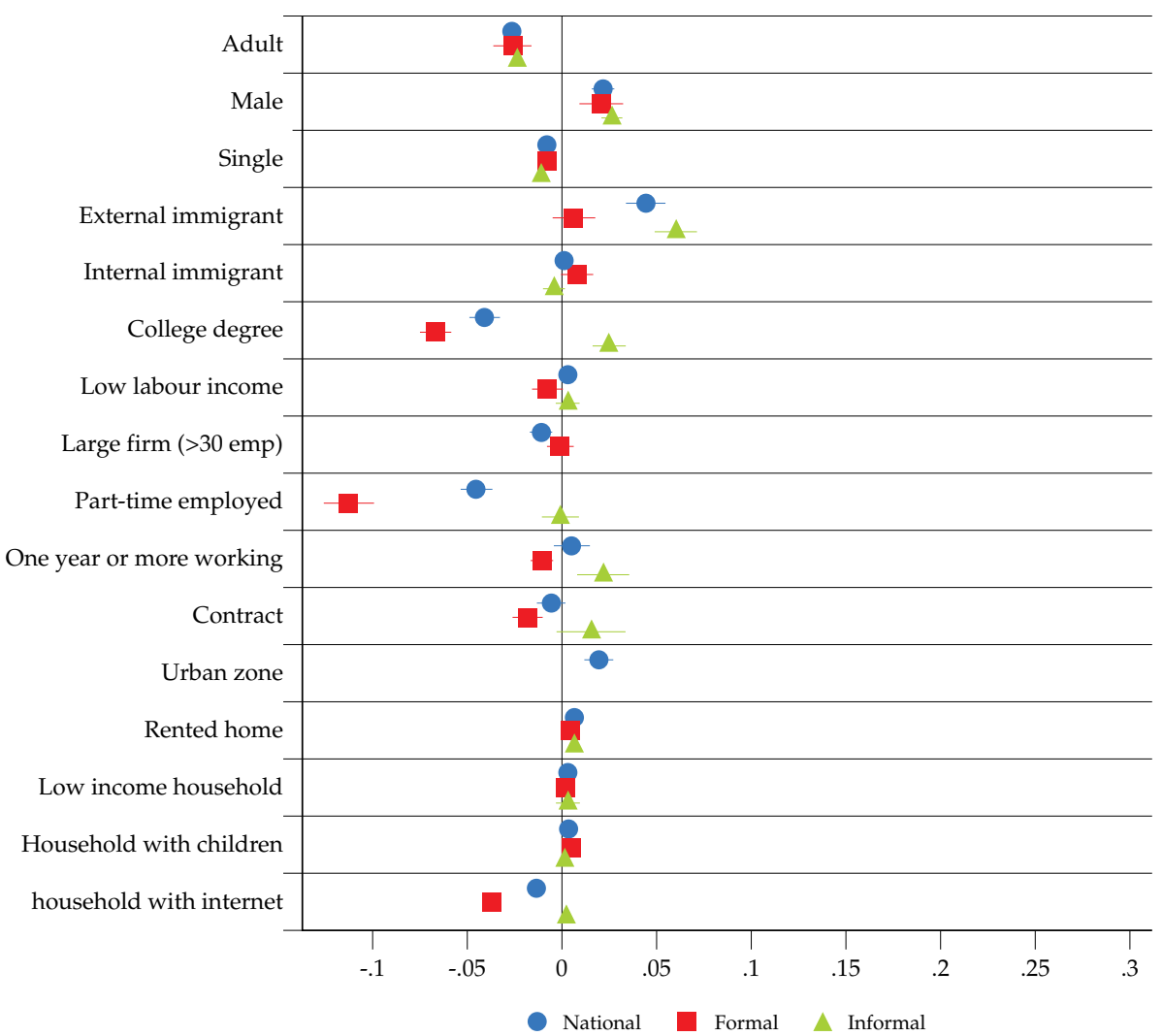

Figure 4. Likelihood of Working in a High Personal-Proximity Occupation, by Job Type (Formal/Informal)

Source: Own calculations based on DANE-GEIH 2016-2019.

compared with its significant negative coefficient in the partial results. Urban zone and rented home are similar to the partial results, as is access to the Internet. Although, the latter is now traceable only to the formal economy, whereas, in the partial results, it was a feature of formal and informal work.

These facts need to be considered in public policy analysis since these occupations will face a change in demand for workers due to contagion prevention. Measures need to be created to protect these employment relationships, which can be accomplished by imposing health and occupational regulations that regain customer confidence or directly compensate the risk taken by workers in such occupations. ${ }^{25}$

25 Table A4 presents the occupations with high-proximity and a higher number of workers. 


\subsection{Household and worker characteristics in face-to-face occupations}

When we take into consideration face-to-face occupations, ${ }^{26}$ at the national, level around $14.9 \%$ of workers hold occupations that involve face-to-face activities. The largest share in high-proximity occupations is in the formal sector, where $16.6 \%$ of workers are required to perform face-to-face tasks (Table 6).

Table 6. Share of Workers in Occupations Intensive in Face-To-Face Interactions

\begin{tabular}{lccc}
\hline & National & Formal & Informal \\
\hline Non-face-to-face occupations & $85.1 \%$ & $83.4 \%$ & $86.1 \%$ \\
Face-to-face occupations & $14.9 \%$ & $16.6 \%$ & $13.9 \%$ \\
\hline
\end{tabular}

Source: Own calculations based on DANE-GEIH 2016-2019.

Figure A3 shows that regions such as Bogotá (centre-south of the country) are characterised by a relatively higher portion of workers in face-toface occupations. Consequently, the maps suggest (Figures A1, A2, and A3) that places like Bogotá are the most affected by the risk of contagion and in terms of all three of the social distancing measures. It is also important to note that Bogotá comprises around $18.6 \%$ of the total Colombian economically active population (Cárdenas, 2020).

Figure 5 illustrates the descriptive results based on the estimation of equation (1), in this case, for individuals in occupations with intensive faceto-face interactions. The discussion of figure 5 first considers the national results, comparing those for face-to-face with those of high-proximity working. It might have been expected that face-to-face would largely be a subgroup of high-proximity working, with a considerable degree of overlap at least in the signs of the partial coefficients; however, in practice, the overlap between the two groups is quite low (only $4 \%$ of individuals report both high-proximity and face-to-face working). Hence, the face-to-face results are of interest in their own right; interestingly, this type of working involves a fairly distinct sub-set of occupations (e. g., lawyers, primary school teachers, psychologists, amongst others). Policies to mitigate the risk of contagion, in such a set of occupations, will depend on its ability to adapt and perform

26 As pointed out earlier, face-to-face contains information on the work context of an occupation, and reflects the frequency that a person must have face-to-face discussions, including co-workers or team members. 
their job task from home and the indispensability of the tasks carried out (e. g., maintaining the provision of public goods), amongst other things. For jobs that are suited to working-from-home and are indispensable, public intervention is required to assure the availability of protective measures and, if necessary, compensation for the hazard of being exposed to the virus.

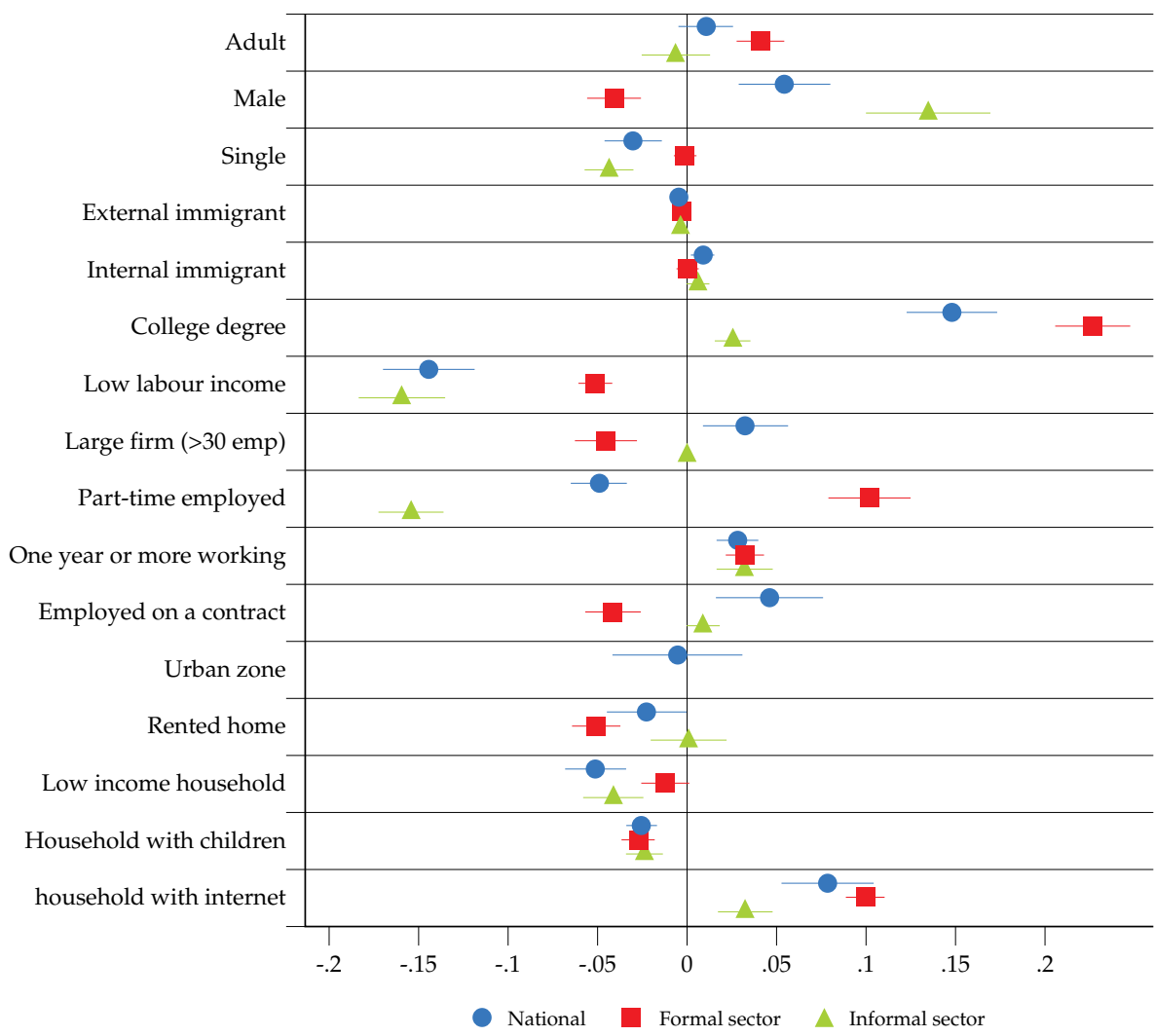

Figure 5. Characteristics of Workers in Face-To-Face Occupations, by Formal and Informal Work

Source: Own calculations based on DANE-GEIH 2016-2019.

The main results of the comparisons of the face-to-face results with those of high-proximity are as follows: males are more likely to be at risk both in terms of face-to-face and high-proximity occupations (with coefficients of about $6 \%$ ), while labour income coefficients are both negative, but of different magnitudes (-14.4 and $-4.7 \%$ ), working in a large firm has fairly similar positive coefficients ( 3.3 and $6.6 \%$ respectively), working part-time is associated with dissimilar negative coefficients (-4.9 and $-11.1 \%$ ) and employed on 
a contract has positive coefficients in both cases (4.6 and 6.8\% respectively). Broadly speaking, out of the 16 characteristics, the results suggest that six appear both relatively important, with the same sign (negative or positive). There are four characteristics associated with a change in sign, but these are smaller in absolute magnitude and generally only significant for one of the two measures (e. g., either face-to-face or high-proximity). The most important of these is holding a college degree which has an insignificant coefficient for high-proximity $(-0.5 \%)$ and a highly significant coefficient for face-to-face $(14.8 \%)$.

The comparisons between the descriptive statistics for the formal and informal sectors in figure 5 do not uniformly show that informal workers are more disadvantaged than formal ones. Amongst the significant partial coefficients, there are two changes in sign between formal and informal workers in the case of the face-to-face measure: the coefficient on males is significant negative amongst formal workers (-4.1\%) and significant positive amongst the informal (13.5\%), indicating a higher risk amongst informal workers, on the other hand, the coefficient on part-time working is significantly lower for the informal (-15.4\%) than the formal (10.2\%), consistent with higher risk amongst the formal workforce. Having a college degree has a significant positive coefficient for both groups, though larger in size for formal (22.7\%) than informal (2.6\%). Low labour income and low household income are both significant negative but larger in absolute size (lower risk) for the formal group (-5.1 and $-15.9 \%$, and -1.2 and $-4.1 \%$, respectively).

\subsection{Likelihood of Having a Face-To-Face Occupation}

Figure 6 follows equation (2) and presents the results for the equivalent multivariate analysis (see Table A5 for details). Generally, but not in every case, the multivariate results reduce coefficient sizes to lower (absolute) values than their partial counterparts in the previous section. One of the most important characteristics affecting the likelihood of working in faceto-face occupations is educational attainment, for which the effect is larger for formal than informal workers (11.8 compared with 1.9\%). According to Figure 6, the coefficients on low labour income are both negative, significant, but smaller in absolute size than for the partial results and little difference between the formal and informal sectors (-5.5 and $-4.5 \%$ ). Part-time work is still associated with a significant positive coefficient for the formal sector and a significant negative for the informal, but the absolute coefficients are much smaller (2.8 and $4.7 \%$, respectively). Overall, partly because of small sample issues for the measure of face-to-face working and because there 
are real differences with the other measures, the results are less robust for the intensive face-to-face interactions than for the teleworkability and the high-proximity measures; therefore, they are less supportive for the degree of informal workers' disadvantage.

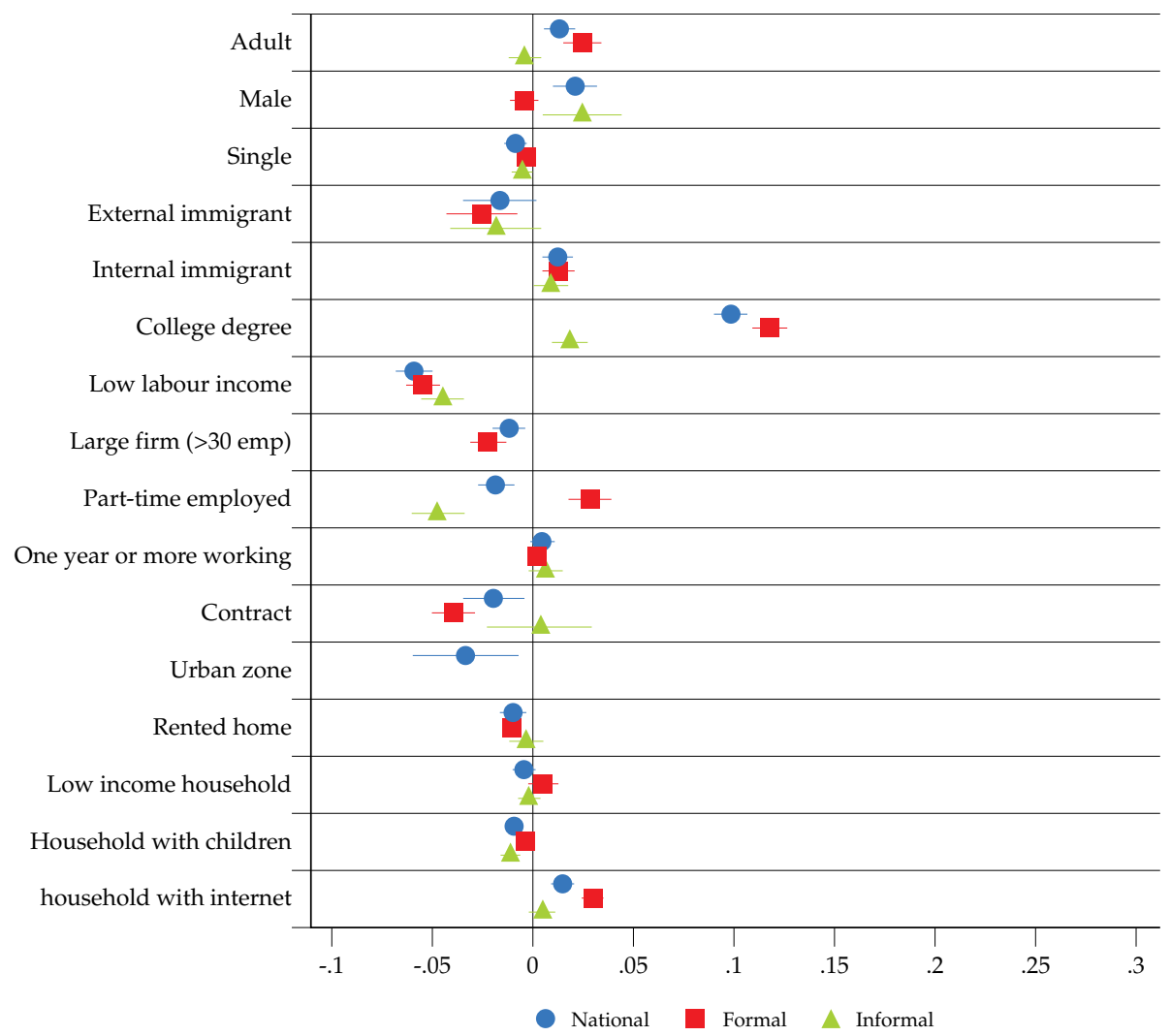

Figure 6. Likelihood of Working in Occupations Intensive in Face-To-Face Interactions, by Formal and Informal Workers

Source: Own calculations based on DANE-GEIH 2016-2019.

\section{Conclusion}

Both the Covid-19 outbreak and the resulting social distancing measures have brought important challenges to the labour market. The present paper contributes to our understanding of the inter-relationship between the labour market and the exposure to covid-19. In particular, it advances the empirical evidence of key global issues by a more inclusive framework that addresses all three dimensions of transmission that have been suggested as transmission 
mechanisms: (i) the inability to work remotely (e. g., from home); (ii) the need for individuals to work in close proximity with other staff, customers, etc.; (iii) the centrality of tasks requiring intensive face-to-face contact.

While the results add to the general body of empirical work, they also contribute from the perspective of developing countries, rather than the primarily developed nation, mainly us-centric literature. Developing countries are more generally characterised by dual economies, in which the informal (rather than formal) economy is considerably more important, if not dominant, compared with the developed nations. Colombia is a useful example, as the degree of informality is relatively high even by South American standards, and a large proportion of the workforce is characterised by low income, a lack of personal wealth, poor working conditions, including an absence of formal contracts and a lack of social support such as unemployment benefits. Thus, covid-19 poses a "contagion or starvation dilemma" amongst the vast majority of the informal workforce.

As with a number of developing countries, Colombia has a well-established and detailed household survey to address many socioeconomic questions; however, the occupational classification adopted in compiling the results is outdated and poses important issues in investigating the workforce exposure to coviD-19. To overcome these problems, this paper provides a methodological contribution that may be of use in other developing countries. The paper highlights the limitations of using crosswalks with aggregated or outdated occupational classifications to determine work-from-home and high-proximity occupations. Second, it reports on how these limitations can be overcome by coding raw occupational responses at an Isco-8 4-digit level, using a mix of methods that includes machine learning techniques. This approach allows the present work to determine the share of people in workfrom-home and high-proximity occupations with much greater precision. Third, this methodology allows the paper to contribute towards the ongoing debate about the use of $\mathrm{O}^{*} \mathrm{NET}$ data in developing countries by comparing the work-from-home results from both $\mathrm{O}^{*} \mathrm{NET}$ and sTEP. The work demonstrates that the two sources lead to similar statistical estimates and allows the data to provide empirical evidence regarding the distribution of work-from-home and high-proximity occupations in the formal and the informal sectors in developing countries such as Colombia.

The results indicate that only around a fifth of Colombian individuals (19.7\%) work in occupations that can potentially be performed remotely and that the percentage for informal workers is considerably lower (13.4\%) than for formal workers (35.4\%). Moreover, the potential effects of social distancing seem to be heterogeneous across different socioeconomic characteristics. 
Taking individual and household characteristics into account, certain characteristics are associated with more vulnerable workers (e. g., low-labour income, low-educated workers, etc.), who are less likely to work remotely. Consequently, the fact that vulnerable people have a higher incidence of working in non-teleworkable occupations makes it difficult to implement social distancing because such workers need to go out to obtain money. In addition, where social distancing can be enforced, these more vulnerable informal workers are likely to suffer greater economic costs.

Just over a tenth of Colombian workers $(10.6 \%)$ hold jobs in high-proximity occupations, considerably lower than in non-teleworkable occupations. The difference between formal and informal workers is not only much smaller, but a higher proportion of formal workers (13.4\%) appear to be more exposed to the risk of the virus than their less vulnerable counterparts $(10.8 \%)$. Overall, $14.9 \%$ of individuals report intensive face-to-face contact and -as in the case of high-proximity workers, the proportion is higher for formal workers $(16.6 \%)$ than informal $(13.9 \%)$. Again —as with high proximity, the percentage point difference is not particularly large. Surprisingly, individuals reporting face-to-face interactions may not be those in high-proximity jobs; only $4 \%$ of individuals fall in both groups, making them quite distinct and explaining, in part, why they have such different results.

While this study cannot say anything about infection rates (e. g., the transmission rates if individuals cannot work-from-home, have high-proximity jobs, or work that involves face-to-face contact), it does indicate that other things being equal, the main issue lies with the fact that certain occupations are not teleworkable. Indeed, while the differences between the informal and formal proportions are relatively low (still over $10 \%$ in both cases) for highproximity and face-to-face work, the proportion of non-teleworkable jobs is much higher (at just under $20 \%$ ) and particularly concentrated amongst the more vulnerable, informal workforce. Finally, the workers who report both high-proximity and face-to-face activities $(4 \%)^{27}$ appear at more risk of contagion; there is a case for policymakers and health authorities to pay special attention to these occupations (e. g., promoting strict security measures or helping workers to obtain necessary security equipment).

The results extend to highlight some of the key personal and family characteristics that are associated with teleworking, high-proximity and face-to-face working. Again, there are both similarities and also important

27 Lawyers, hotel receptionists, retail and wholesale trade managers, etc. 
differences in the results for jobs linked to these three types of working. Three examples are sufficient to illustrate both consistency and diversity: ${ }^{28}$

i. A college degree is associated with a considerably high probability of being in a teleworkable occupation (18.9\%) and much more so in formal $(20.9 \%)$ than informal (5.9\%) occupations. It is negatively related to the probability of being in a high-proximity occupation overall (-4.0\%) in formal $(-6.6 \%)$ but not in informal work (2.5\%). It is positively linked to face-to-face working for all three groups $(0.8 \%, 11.8 \%$, and $1.9 \%$, respectively) - linked to the high-level professional occupations that require face-to-face interaction.

ii. Low labour income is associated with a lower probability of being in a high-proximity occupation (-3.7\%) and more so in formal (-3.1\%) than informal $(-1.7 \%)$ occupation. It is not significantly related (positive or negative) to the probability of being in a high-proximity occupation. It is negatively linked to face-to-face working for all three groups at around $5 \%(-5.9 \%,-5.5 \%$, and $-4.5 \%$, respectively).

iii. External immigrant status is associated with a lower probability of being in a teleworkable occupation (-4.5\%) and somewhat more so in formal $(-6.4 \%)$ than informal $(-3.6 \%)$ occupations. It is positively related to the probability of being in a high-proximity occupation overall $(4.4 \%)$ and in informal work $(6.1 \%)$ but not in informal work (insignificantly different from zero). It is negatively linked to face-to-face working for all three groups $(-1.7 \%,-2.5 \%$, and an insignificant $1.9 \%$, respectively).

Clearly the advice to policymakers and health authorities will differ depending on the virility of the transmission process in each of the three sources of risk, but will also depend on the particular characteristics of individuals.

This paper has advanced in the current understanding of those who are at more (or less) risk to covid-19 through their access to working-fromhome, working in high-proximity, and face-to-face occupations. In addition, the paper throws light on the particular issues within a developing country, where duality between formal and informal working is acute. The present estimations are an important step to help in the design of public policy programs because they allow the more precise identification of the population that might be most affected by covID-19 and social distancing measures, as well as who might benefit the most from a covid-19 vaccine. Furthermore,

28 Taken from the multivariate results (Tables A2, A3, and A4). 
this research introduced new avenues of enquiry for future research. Potentially, these results might help monitor, for instance, labour market changes over time, such as the labour demand and supply between non-teleworkable and teleworkable occupations, possible heterogeneous effects on wages and hours worked between occupations, among other topics.

\section{References}

Avdiu, B., \& Nayyar, G. (2020). When face-to-face interactions become an occupational hazard: Jobs in the time of COVID-19. World Bank. https://openknowledge.worldbank.org/handle/10986/33752

Bello, S. L., Sánchez Puerta, M. L., \& Winkler, H. (2019). From Ghana to America: The skill content of jobs and economic development. World Bank. https:// openknowledge.worldbank.org/handle/10986/31332

Bonnet, F., Vanek, J., \& Chen, M. (2019). Women and men in the informal economy: A statistical brief. wIEGo. https://www.ilo.org/wcmsp5/groups/ public/-ed_protect/_-protrav/_-travail/documents/publication/ wcms_711798.pdf

Bosworth, D. L., Dawkins, P. J., \& Strombach, T. (1996). The economics of the labour market. Longmans.

Cárdenas, J. (2020). Extracting value from job vacancy information. Alianza EFI. https://alianzaefi.com/download/extracting-value-from-job-vacancyinformation/

Chakrabarti, R., Pinkovskiy, M., Nober, W., \& Meyerson, L. (2020, September 25). Investigating the effect of health insurance in the COVID-19 pandemic. Liberty Street Economics. https://libertystreeteconomics.newyorkfed. org/2020/09/investigating-the-effect-of-health-insurance-in-the-covid-19-pandemic.html

DANE. (2009). Metodología. Gran Encuesta Integrada de Hogares. https://www. dane.gov.co/files/investigaciones/fichas/Gran_encuesta_integrada_ hogares.pdf

Del Rio-Chanona, M., Mealy, P., Pichler, A., Lafond, F., \& Farmer, D. (2020). Supply and demand shocks in the COVID-19 pandemic: An industry and occupation perspective. Oxford Martin School. https://www.oxfordmartin.ox.ac.uk/publications/supply-and-demand-shocks-in-the-COVID19-pandemic-an-industry-and-occupation-perspective/

Delaporte, I., \& Peña, W. (2020). Working from home under covid-19: Who is affected? Evidence from Latin American and Caribbean countries. Evidence from Latin American and Caribbean Countries. CEPR COVID Economics, 14. https://ssrn.com/abstract=3610885 
Dingel, J. I., \& Neiman, B. (2020). How many jobs can be done at home? Technical Report. National Bureau of Economic Research, (189). https:// doi.org/10.1016/j.jpubeco.2020.104235

Gweon, H., Schonlau, M., Kaczmirek, L., Blohm, M., \& Steiner, S. (2017). Three methods for occupation coding based on statistical learning. Journal of Official Statistics, 33(1), 101-122. https://www.ssoar.info/ssoar/handle/ document/61576

ILO. (2020a). COVID-19 crisis and the informal economy: Immediate responses and policy challenges. International Labour Organization. https://www.ilo. org/global/topics/employment-promotion/informal-economy/publications/WCMS_743623/lang-en/index.htm

ILO. (2020b). Contagion or starvation, the dilemma facing informal workers during the COVID-19 pandemic. International Labour Organization. https:// www.ilo.org/global/about-the-ilo/newsroom/news/WCMS_744005/ lang_en/index.htm

Leibovici, F., Santacreu, A. M., \& Famiglietti, M. (2020, March 24). Social Distancing and Contact-Intensive Occupations. St. Louis Fed On the Economy blog. https://www.stlouisfed.org/on-the-economy/2020/march/socialdistancing-contact-intensive-occupations

Margolis, D. N. (2014). By choice and by necessity: Entrepreneurship and selfemployment in the developing world. European Journal of Development Research, 26(4), 419-436. https://doi.org/10.1057/ejdr.2014.25

Mongey, S., \& Weinberg, A. (2020). Characteristics of workers in low work-fromhome and high personal-proximity occupations. Becker Friedman Institute. https://bfi.uchicago.edu/working-paper/characteristics-of-workers-inlow-work-from-home-and-high-personal-proximity-occupations/

Mongey, S., Pilossoph, L., \& Weinberg, A. (2020). Which workers bear the burden of social distancing policies? Technical Report No. 27085. National Bureau of Economic Research. https://www.nber.org/papers/w27085?sy=085 Onetcenter. (2016). About $O^{*} N E T$. https://www.onetcenter.org/overview.html ONs. (2020). Which Occupations have the Highest Potential Exposure to the Coronavirus (COVID-19)?. Office for National Statistics. https://www.ons.gov. uk/employmentandlabourmarket/peopleinwork/employmentandemployeetypes/articles/whichoccupationshavethehighestpotentialexposuretothecoronavirusCOVID19/2020-05-11

Perry, G. E., Arias, O., Fajnzylber, P., Maloney, W. F., Mason, A., \& SaavedraChanduvi, J. (2007). Informality: exit and exclusion. World Bank. https:// openknowledge.worldbank.org/handle/10986/6730

Pierre, G., Sánchez Puerta, M. L., Valerio, A., \& Rajadel, T. (2014). STEP skills measurement surveys: Innovative tools for assessing skills. https:// 
openknowledge.worldbank.org/bitstream/handle/10986/19985/8972 90NWP0P132085290B00PUBLIC001421.pdf?sequence $=1 \&$ isAllowed $=y$ Piore, M. J. (2014). The dual labour market. Theory and applications. In R. Barringer \& S. H. Beer (Eds.), The State and the Poor. (pp. 55-59). Winthrop. Pratap, S., \& Quintin, E. (2006). The Informal Sector in Developing Countries: Output, Assets and Employment (wIDER Research Paper, n. ${ }^{\circ}$ 130). United Nations University World Institute for Development. https://www. wider.unu.edu/publication/informal-sector-developing-countries

Presidencia de la República. (2020, 22 de marzo). [Decreto 457 de 2020] Por el cual se imparten instrucciones en virtud de la emergencia sanitaria generada por la pandemia del Coronavirus CoviD-19 y el mantenimiento del orden público. https://dapre.presidencia.gov.co/normativa/normativa/ DECRETO\%20457\%20DEL\%2022\%20DE\%20MARZO\%20DE\%202020.pdf

Saltiel, F. (2020). Who can work from home in developing countries? COVID Economics, 7, 104-118.

Williams, C. C. (2014). Out of the shadows: A classification of economies by the size and character of their informal sector. Work, Employment and Society, 28(5), 735-753. 


\section{Annex}

\section{Tables}

Table A1. Descriptive statistics, formal and informal sectors

\begin{tabular}{|c|c|c|c|}
\hline Variable & National & Formal & Informal \\
\hline \multicolumn{4}{|l|}{ Worker characteristics } \\
\hline Adult (> 50 years) & $25.7 \%$ & $16.3 \%$ & $32.0 \%$ \\
\hline Male & $58.3 \%$ & $56.7 \%$ & $54.1 \%$ \\
\hline Single & $42.0 \%$ & $44.2 \%$ & $43.0 \%$ \\
\hline External immigrant & $1.7 \%$ & $1.4 \%$ & $2.7 \%$ \\
\hline Internal immigrant & $11.6 \%$ & $12.8 \%$ & $9.6 \%$ \\
\hline College degree & $22.6 \%$ & $44.3 \%$ & $11.4 \%$ \\
\hline Urban zone & $78.3 \%$ & - & - \\
\hline \multicolumn{4}{|l|}{ Job characteristics } \\
\hline Low labour income & $42.1 \%$ & $14.4 \%$ & $64.0 \%$ \\
\hline Large firm (>30 emp) & $26.5 \%$ & $67.4 \%$ & - \\
\hline Part-time employed & $43.3 \%$ & $29.2 \%$ & $46.8 \%$ \\
\hline One year or more working & $71.3 \%$ & $67.5 \%$ & $71.4 \%$ \\
\hline Contract & $33.9 \%$ & $80.3 \%$ & $5.2 \%$ \\
\hline Agriculture, hunting, and forestry & $16.4 \%$ & $2.6 \%$ & $5.3 \%$ \\
\hline Mining and quarrying & $0.9 \%$ & $1.0 \%$ & $0.3 \%$ \\
\hline Manufacturing & $11.8 \%$ & $16.0 \%$ & $11.0 \%$ \\
\hline Electricity, gas, and water supply & $0.5 \%$ & $1.3 \%$ & $0.0 \%$ \\
\hline Construction & $6.4 \%$ & $5.8 \%$ & $8.8 \%$ \\
\hline Wholesale, retail trade, hotels, and restaurants & $27.3 \%$ & $19.1 \%$ & $39.9 \%$ \\
\hline Transport, storage, and communications & $8.0 \%$ & $6.7 \%$ & $11.7 \%$ \\
\hline Financial intermediation & $1.4 \%$ & $3.3 \%$ & $0.4 \%$ \\
\hline Real estate, renting, and business activities & $7.8 \%$ & $12.7 \%$ & $6.9 \%$ \\
\hline \multirow[t]{2}{*}{ Community, social, and personal service activities } & $19.6 \%$ & $31.6 \%$ & $15.7 \%$ \\
\hline & $100.0 \%$ & $100.0 \%$ & $100.0 \%$ \\
\hline
\end{tabular}




\begin{tabular}{lccc}
\hline \multicolumn{1}{c}{ Variable } & National & Formal & Informal \\
\hline Household characteristics & & & \\
Rented home & $38.0 \%$ & $49.1 \%$ & $43.9 \%$ \\
Low household income & $35.2 \%$ & $12.2 \%$ & $35.8 \%$ \\
Household with children (<6 years old) & $30.2 \%$ & $28.9 \%$ & $29.8 \%$ \\
Household with Internet & $42.9 \%$ & $64.8 \%$ & $41.0 \%$ \\
\hline
\end{tabular}

Source: Own calculations based on DANE-GEIH 2016-2019.

Table A2. Influences on teleworkability, formal and informal sectors

\begin{tabular}{|c|c|c|c|}
\hline Variables & National & Formal & Informal \\
\hline \multirow{2}{*}{ Adult } & $0.006^{*}$ & $0.031^{* * *}$ & $-0.012^{* * *}$ \\
\hline & $(0.003)$ & $(0.006)$ & $(0.003)$ \\
\hline \multirow{2}{*}{ Male } & -0.004 & $-0.032^{* * *}$ & $-0.015^{*}$ \\
\hline & $(0.005)$ & $(0.006)$ & $(0.008)$ \\
\hline \multirow{2}{*}{ Single } & 0.002 & $0.009^{* * *}$ & -0.001 \\
\hline & $(0.002)$ & $(0.002)$ & $(0.002)$ \\
\hline \multirow{2}{*}{ External immigrant } & $-0.045^{* * *}$ & $-0.036^{* * *}$ & $-0.064^{* * *}$ \\
\hline & $(0.007)$ & $(0.008)$ & $(0.008)$ \\
\hline \multirow{2}{*}{ Internal immigrant } & $-0.015^{* * *}$ & $-0.028^{* * *}$ & -0.000 \\
\hline & $(0.004)$ & $(0.005)$ & $(0.005)$ \\
\hline \multirow{2}{*}{ College degree } & $0.189^{* * *}$ & $0.209^{* * *}$ & $0.059^{* * *}$ \\
\hline & $(0.005)$ & $(0.006)$ & $(0.006)$ \\
\hline \multirow{2}{*}{ Low labour income } & $-0.037^{* * *}$ & $-0.031^{* * *}$ & $-0.017^{* * *}$ \\
\hline & $(0.004)$ & $(0.005)$ & $(0.006)$ \\
\hline \multirow{2}{*}{ Large firm (>30 emp) } & $0.030^{* * *}$ & $-0.017^{* * *}$ & \\
\hline & $(0.005)$ & $(0.004)$ & \\
\hline \multirow{2}{*}{ Part-time employed } & $0.074^{* * *}$ & $0.203^{* * *}$ & -0.003 \\
\hline & $(0.005)$ & $(0.009)$ & $(0.006)$ \\
\hline \multirow{2}{*}{ One year or more working } & $-0.007^{* *}$ & $0.014^{* * *}$ & $-0.023^{* * *}$ \\
\hline & $(0.003)$ & $(0.003)$ & $(0.004)$ \\
\hline \multirow{2}{*}{ Employed on a contract } & $0.098^{* * *}$ & $0.044^{* * *}$ & $0.095^{* * *}$ \\
\hline & $(0.009)$ & $(0.006)$ & $(0.017)$ \\
\hline
\end{tabular}




\begin{tabular}{lccc}
\hline \multicolumn{1}{c}{ Variables } & National & Formal & Informal \\
\hline Urban zone & $-0.015^{*}$ & & \\
& $(0.008)$ & & \\
Rented home & $-0.011^{* * *}$ & $-0.019^{* * *}$ & -0.002 \\
& $(0.003)$ & $(0.003)$ & $(0.003)$ \\
Low-income household & $-0.015^{* * *}$ & -0.008 & $-0.011^{*}$ \\
Household with children & $(0.005)$ & $(0.005)$ & $(0.006)$ \\
Household with Internet & $-0.013^{* * *}$ & $-0.014^{* * *}$ & $-0.010^{* * *}$ \\
\hline
\end{tabular}

Robust standard errors in parentheses; ${ }^{* *} \mathrm{p}<0.01,{ }^{* *} \mathrm{p}<0.05,{ }^{*} \mathrm{p}<0.1$. Sector and year dummies included, but not reported.

Table A3. Influences on proximity, formal and informal sectors

\begin{tabular}{|c|c|c|c|}
\hline Variables & National & Formal & Informal \\
\hline \multirow{2}{*}{ Adult } & $-0.026^{* * *}$ & $-0.026^{* * *}$ & $-0.023^{* * *}$ \\
\hline & $(0.002)$ & $(0.005)$ & $(0.002)$ \\
\hline \multirow{2}{*}{ Male } & $0.022^{* * *}$ & $0.021^{* * *}$ & $0.027^{* * *}$ \\
\hline & $(0.003)$ & $(0.006)$ & $(0.003)$ \\
\hline \multirow{2}{*}{ Single } & $-0.008^{* * *}$ & $-0.008^{* * *}$ & $-0.011^{* * *}$ \\
\hline & $(0.001)$ & $(0.002)$ & $(0.001)$ \\
\hline \multirow{2}{*}{ External immigrant } & $0.044^{* * *}$ & 0.007 & $0.061^{* * *}$ \\
\hline & $(0.005)$ & $(0.006)$ & $(0.005)$ \\
\hline \multirow{2}{*}{ Internal immigrant } & 0.001 & $0.008^{*}$ & -0.004 \\
\hline & $(0.002)$ & $(0.004)$ & $(0.003)$ \\
\hline \multirow{2}{*}{ College degree } & $-0.040^{* * *}$ & $-0.066^{* * *}$ & $0.025^{* * *}$ \\
\hline & $(0.004)$ & $(0.004)$ & $(0.004)$ \\
\hline \multirow{2}{*}{ Low labour income } & 0.003 & $-0.008^{*}$ & 0.003 \\
\hline & $(0.002)$ & $(0.004)$ & $(0.003)$ \\
\hline \multirow{2}{*}{ Large firm (>30 emp) } & $-0.011^{* * *}$ & -0.000 & \\
\hline & $(0.003)$ & $(0.004)$ & \\
\hline
\end{tabular}




\begin{tabular}{lccc}
\hline \multicolumn{1}{c}{ Variables } & National & Formal & Informal \\
\hline Part-time employed & $-0.045^{* * *}$ & $-0.112^{* * *}$ & -0.001 \\
One year or more working & $(0.004)$ & $(0.007)$ & $(0.005)$ \\
Employed on a contract & 0.005 & $-0.010^{* * *}$ & $0.022^{* * *}$ \\
& $(0.005)$ & $(0.003)$ & $(0.007)$ \\
Urban zone & -0.005 & $-0.018^{* * *}$ & $0.016^{*}$ \\
Rented home & $(0.004)$ & $(0.004)$ & $(0.009)$ \\
Low-income household & $0.020^{* * *}$ & & \\
& $(0.004)$ & & \\
Household with children & $0.007^{* * *}$ & $0.005^{* * *}$ & $0.007^{* * *}$ \\
Household with Internet & $(0.001)$ & $(0.002)$ & $(0.002)$ \\
& 0.003 & 0.002 & 0.003 \\
& $(0.002)$ & $(0.002)$ & $(0.003)$ \\
& $0.004^{* * *}$ & $0.006^{* * *}$ & 0.002 \\
\hline & $(0.001)$ & $(0.001)$ & $(0.001)$ \\
& $-0.013^{* * *}$ & $-0.037^{* * *}$ & 0.003 \\
& $(0.002)$ & $(0.002)$ & $(0.002)$ \\
\hline
\end{tabular}

Robust standard errors in parentheses; ${ }^{* * *} \mathrm{p}<0.01,{ }^{* *} \mathrm{p}<0.05,{ }^{*} \mathrm{p}<0.1$. Sector and year dummies included, but not reported.

Table A4. Occupations that are performed with high proximity and with a higher number of workers

\begin{tabular}{lc}
\hline \multicolumn{1}{c}{ Occupations } & Percentage \\
\hline Bricklayers and related workers & $2.91 \%$ \\
Security guards & $2.05 \%$ \\
Beauticians and related workers & $1.25 \%$ \\
Personal care workers in health services and related workers & $0.66 \%$ \\
Nursing professionals & $0.59 \%$ \\
Health care assistants & $0.50 \%$ \\
Hairdressers & $0.37 \%$ \\
Home-based personal care workers & $0.24 \%$ \\
Dentists & $0.22 \%$ \\
Food service counter attendants & $0.14 \%$ \\
\hline
\end{tabular}

Source: Own calculations based on DANE-GEIH 2016-2019. 
Table A5. Influences on face-to-face, formal and informal sectors

\begin{tabular}{|c|c|c|c|}
\hline Variables & National & Formal & Informal \\
\hline \multirow{2}{*}{ Adult } & $0.013^{* * *}$ & $0.025^{* * *}$ & -0.004 \\
\hline & $(0.004)$ & $(0.005)$ & $(0.004)$ \\
\hline \multirow{2}{*}{ Male } & $0.021^{* * *}$ & -0.005 & $0.025^{* *}$ \\
\hline & $(0.005)$ & $(0.003)$ & $(0.010)$ \\
\hline \multirow{2}{*}{ Single } & $-0.008^{* * *}$ & $-0.003^{*}$ & $-0.005^{* *}$ \\
\hline & $(0.003)$ & $(0.002)$ & $(0.003)$ \\
\hline \multirow{2}{*}{ External immigrant } & $-0.017^{*}$ & $-0.025^{* * *}$ & -0.019 \\
\hline & $(0.009)$ & $(0.009)$ & $(0.011)$ \\
\hline \multirow{2}{*}{ Internal immigrant } & $0.012^{* * *}$ & $0.013^{* * *}$ & $0.009^{* *}$ \\
\hline & $(0.004)$ & $(0.004)$ & $(0.004)$ \\
\hline \multirow{2}{*}{ College degree } & $0.098^{* * *}$ & $0.118^{* * *}$ & $0.019^{* * *}$ \\
\hline & $(0.004)$ & $(0.004)$ & $(0.004)$ \\
\hline \multirow{2}{*}{ Low labour income } & $-0.059^{* * *}$ & $-0.055^{* * *}$ & $-0.045^{* * *}$ \\
\hline & $(0.005)$ & $(0.004)$ & $(0.005)$ \\
\hline \multirow{2}{*}{ Large firm (>30 emp) } & $-0.012^{* * *}$ & $-0.022^{* * *}$ & \\
\hline & $(0.004)$ & $(0.004)$ & $\mathrm{n} / \mathrm{a}$ \\
\hline \multirow{2}{*}{ Part-time employed } & $-0.018^{* * *}$ & $0.028^{* * *}$ & $-0.047^{* * *}$ \\
\hline & $(0.004)$ & $(0.005)$ & $(0.006)$ \\
\hline \multirow{2}{*}{ One year or more working } & 0.005 & 0.002 & 0.006 \\
\hline & $(0.003)$ & $(0.002)$ & $(0.004)$ \\
\hline \multirow{2}{*}{ Employed on a contract } & $-0.020^{* *}$ & $-0.040^{* * *}$ & 0.003 \\
\hline & $(0.007)$ & $(0.005)$ & $(0.013)$ \\
\hline \multirow{2}{*}{ Urban zone } & $-0.033^{* *}$ & & \\
\hline & $(0.013)$ & $\mathrm{n} / \mathrm{a}$ & $\mathrm{n} / \mathrm{a}$ \\
\hline \multirow{2}{*}{ Rented home } & $-0.010^{* * *}$ & $-0.011^{* * *}$ & -0.003 \\
\hline & $(0.003)$ & $(0.002)$ & $(0.004)$ \\
\hline \multirow{2}{*}{ Low-income household } & -0.005 & 0.005 & -0.002 \\
\hline & $(0.003)$ & $(0.004)$ & $(0.003)$ \\
\hline \multirow{2}{*}{ Household with children } & $-0.009^{* * *}$ & -0.004 & $-0.011^{* * *}$ \\
\hline & $(0.002)$ & $(0.002)$ & $(0.002)$ \\
\hline Household with Internet & $0.015^{* * *}$ & $0.030^{* * *}$ & 0.005 \\
\hline
\end{tabular}

Robust standard errors in parentheses; ${ }^{* *} \mathrm{p}<0.01,{ }^{* *} \mathrm{p}<0.05,{ }^{*} \mathrm{p}<0.1$. Sector and year dummies included, but not reported. N/A indicates that the coefficients cannot be estimated separately for the formal and/ or informal groups. 


\section{Figures}

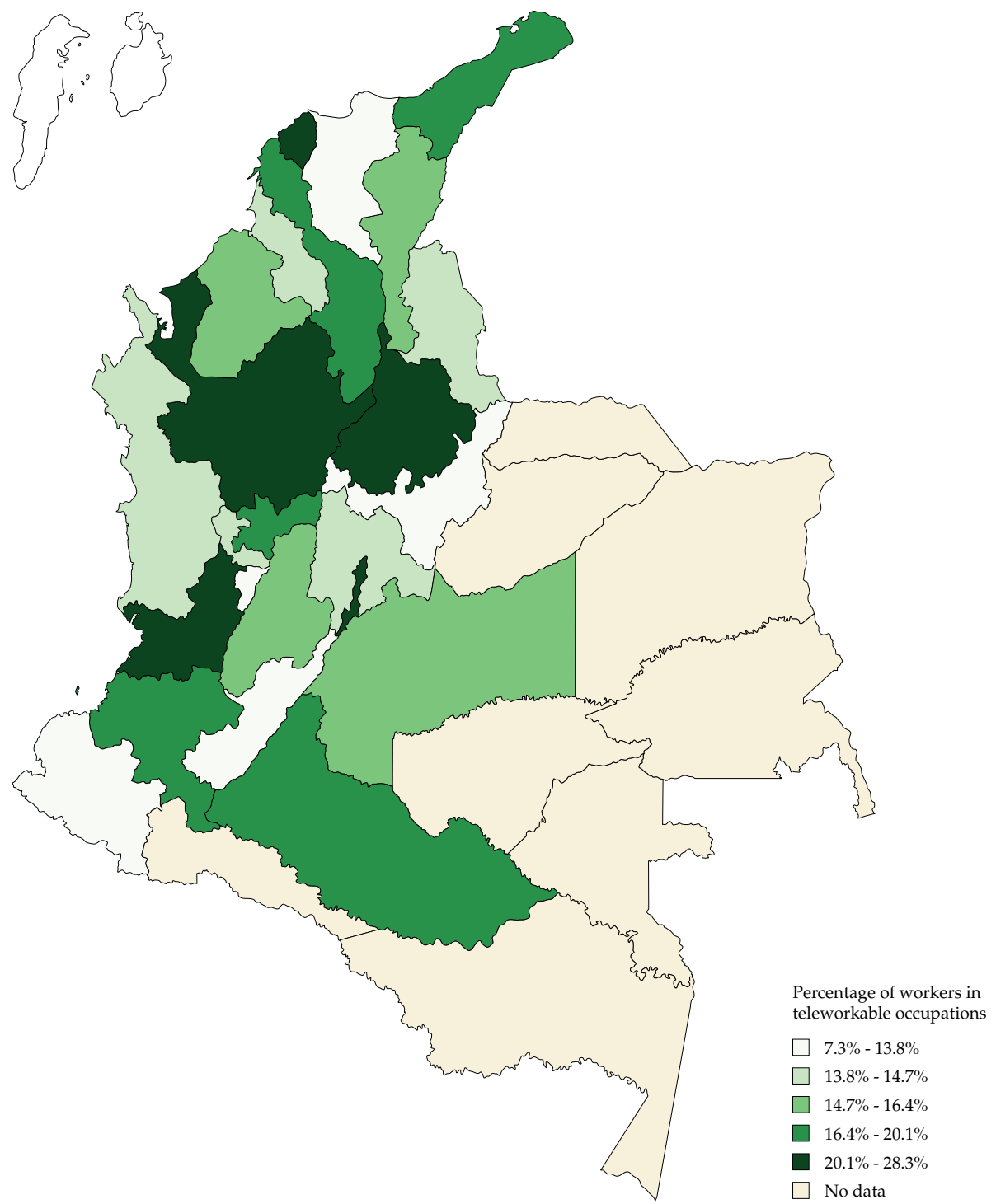

Figure A1. Share of workers in teleworkable occupations by region

Source: DANE-GEIH 2016-2019. 


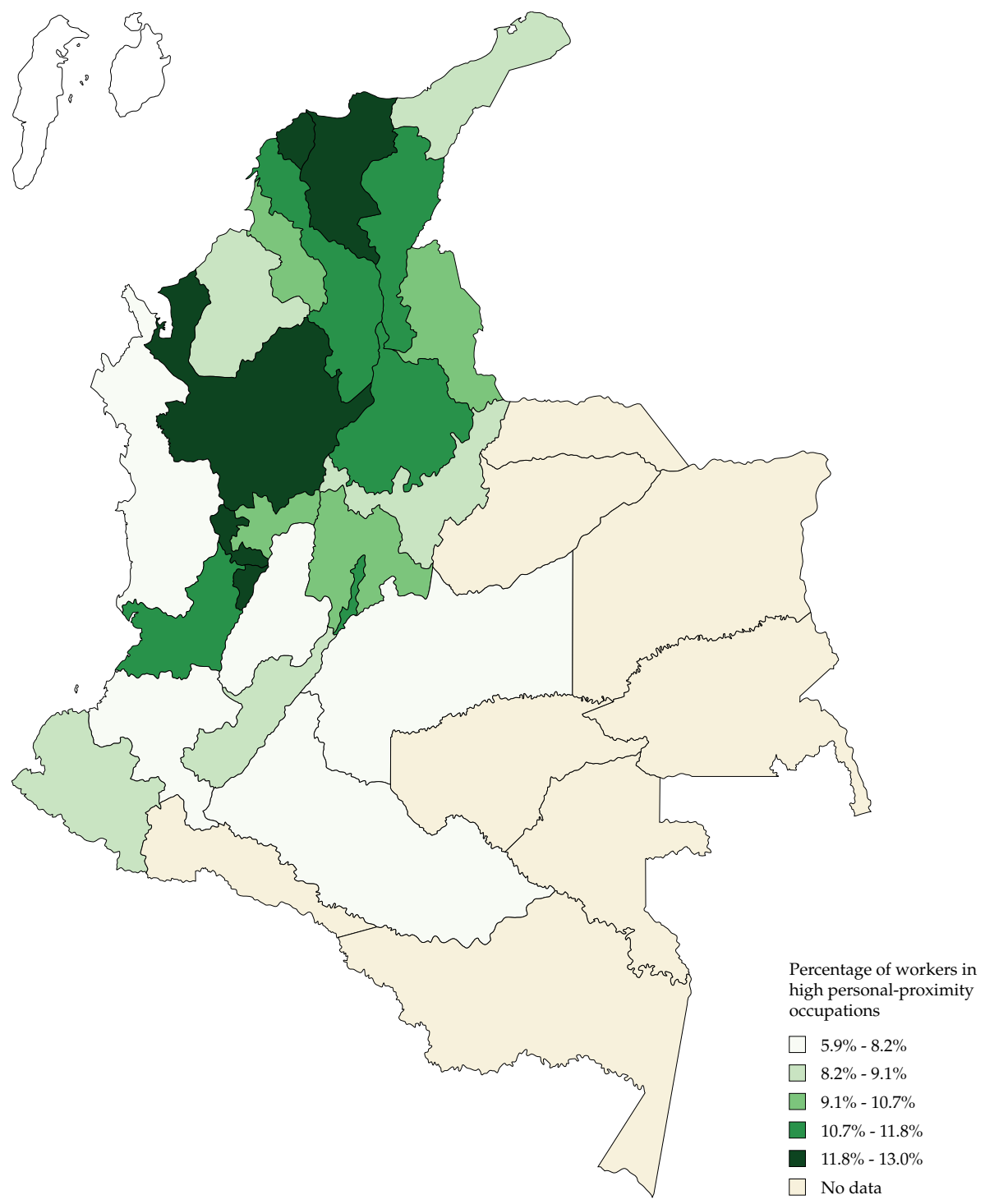

Figure A2. Share of workers in high personal-proximity occupations by region Source: Own calculations based on DANE-GEIH 2016-2019. 


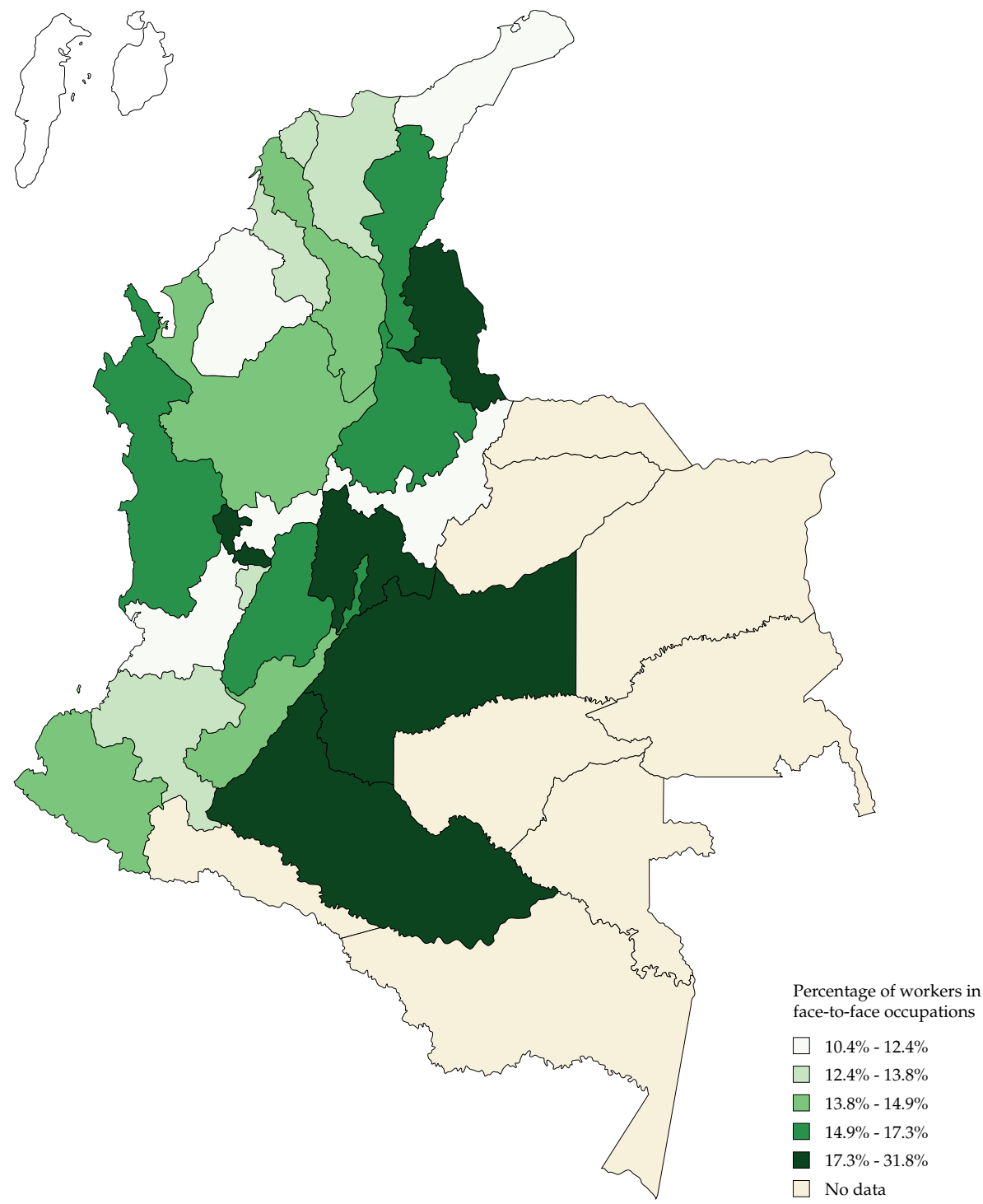

Figure A3. Share of workers in face-to-face occupations by region.

Source: Own calculations based on DANE-GEIH 2016-2019. 